\title{
IS THERE A HOUSING BUBBLE IN TURKEY?
}

\author{
Yener Coskun, PhD \\ Capital Market Board of Turkey \\ e-mail:ycoskun@spk.gov.tr
}

\author{
Arvydas Jadevicius, PhD \\ Royal Agricultural University \\ e-mail: ajadevicius@gmail.com
}

\begin{abstract}
There was a notable housing price inflation in aggregate/local levels in Turkey during the last few years. Although the country's economic fundamentals remain strong, the probability of a housing bubble is a heated debate among market participants. This timely investigation brings greater clarity to whether the Turkish housing market is in a bubble. The study uses a multi-strand approach to dissect the bubble over the period of Jan. 2010 - Dec. 2014. First, monthly/annual price-to-income and monthly price-to-rent ratios are examined for the national Turkish as well as regional Istanbul, Izmir and Ankara housing markets. Second, an extended CASE and SHILLER (2003) model is applied assessing the interdependence between housing prices and a series of explanatory variables. Lastly, the Right Tail Augmented Dickey-Fuller (Rtadf) test is performed to support the overall analysis. This study finds that neither affordability ratios nor regression estimates support the existence of the bubble in Turkey.
\end{abstract}

Key words: Housing bubble, regression analysis, affordability ratios, Rtadf, Turkish housing market, Istanbul housing market.

JEL Classification: R31, E44, G01.

Citation: Coskun Y., Jadevicius A., 2017, Is there a Housing Bubble in Turkey?, Real Estate Management and Valuation, vol. 25, no. 1, pp. 48-73.

DOI: $10.1515 /$ remav-2017-0003

\section{Introduction}

There is a general agreement that speculative behaviors affecting housing prices may result in bubbles that subsequently collapse, affecting governments, businesses and individuals (AKERLOF, SHILLER 2009; Kindleberger, Aliber 2005; SHILler 2006, 2014a). The collapse of the housing market can produce wide-ranging repercussions, including foreclosures, a decline in construction and manufacturing, tightening of mortgages, negative equity, as well as knock-on effects on employment, the local and national economy and, potentially, overall economic malaise (e.g. MARTIN 2011). As such, the issue of bubbles has become a topic of debate amongst academics (e.g. MiLLER, STIGLITZ 2010), professionals (e.g. JONES 2014) and the media (e.g. GOODKIND 2014).

In Turkey, housing prices have recently experienced a notable increase. The rise of new residential and commercial properties has changed the landscape of major cities, particularly Istanbul. Though seen as positive by many, rising property prices have also made observers question whether the national housing market may be in a bubble. Numerous global institutions/international media outlets have expressed their concerns. Their concern is that if the Turkish housing market is in a bubble and this is not addressed systematically, prices will fall precipitously at some future date. Collapsing housing prices will, in turn, affect not only homeowners, but also banks, property developers, and the overall national economy. 
There has been much less discussion on the issue of a national housing bubble utilizing comprehensive analyses in academic circles. The current study fills this gap. It employs a multi-strand approach to assess whether the housing market is in a bubble in aggregate/local levels in Turkey. There are, however, three significant challenges to such a study. Firstly, there are no readily available official data on price-to-income and price-to-rent ratios and, secondly, no extensive regional/city level series or variables that have been properly used in housing market analysis. Thirdly, the observation period is necessarily short, because the employed housing price series started in 2010. Although the latter two challenges, for the most part, constitute acceptable limitations, our study contributes to literature by addressing the first challenge. By using national level data, the study is the first to attempt to construct monthly price-to-income and price-to-rent affordability series for Turkey, Istanbul, Ankara and Izmir in an academic study. We also construct first time aggregate/local level annual price-to-income ratios by utilizing province level income data. The analysis then turns to CASE and SHILLER's (2003) modelling framework to analyze whether aggregate/local housing prices show bubble behavior. We also broaden the framework with an introduction of auxiliary variables. Right Tail Augmented Dickey-Fuller (Rtadf) tests are additionally employed for the purpose of robustness.

The remainder of the paper is as follows. Section 2 introduces the reader to the condition of the Turkish housing market. Section 3 involves a review of literature by analyzing theoretical/empirical frameworks with a specific focus on selected emerging markets (such as China and Brazil) and Turkey. Section 4 introduces data construction, methodologies and a summary of statistics. Section 5 presents empirical estimates and discussions for model outcomes of affordability ratios and all regression analyses. Section 6 concludes the study.

\section{Turkish Housing Market: Some Facts}

Over the last decade, the Turkish economy was among the fastest growing economies in the world. World Bank and IMF backed economic policies after the local banking crisis in 2000-2001, a stable macro-economic environment combined with a good regulatory background and lending standards contributed to this expansion. ${ }^{1}$

YALCINER and COSKUN (2014) illustrate this transformation ${ }^{2}$ particularly well from the perspective of the housing market. Declining mortgage rates significantly contributed to a surge in propertyrelated activities. The mortgage loan rate dropped from 55 per cent in April 2002 to 11 per cent in March 2015. Mortgage loan volumes grew 31,215 per cent between December 2002 and February 2015. The size of construction loans grew by 1,047 per cent over the same time period. The number of mortgage credit users has also risen significantly. It grew from 0.03 million to 1.8 million between September 2002 and September 2014. The number of housing sales increased from nearly 0.43 million units to 1.16 million units between 2008 and 2014, a 173 per cent increase. All in all, declining mortgage rates, growing income/wealth, a good regulatory framework, government support for the construction/housing sector, and rising international demand ${ }^{3}$ over the last decade all contributed to substantial economic expansion in general, and housing market activity in particular. Fig. 1 below presents some of these trends.

ULI and PwC (2012) indicate that Ireland and Turkey are the most optimistic countries in the region. THE BROOKINGS INSTITUTION (2015) further suggests that Izmir, Istanbul, Bursa, and Ankara are ranked as second, third, fourth, and ninth, among 300 of the largest metropolitan economies in the world. According to COSKUN (2011), WORLD BANK (2015), and TURKSTAT (2015a), a growing economy combined with an inflow of foreign investment, rising income, easy access to financing and a growing population all had a positive effect on Turkey's property market. STANDARD \& POOR'S

\footnotetext{
1 Despite significant economic growth over the last decade, the Turkish economy is not without difficulties. RODRIK (2012) argues that the Turkish economic model, which relies on foreign savings and large currentaccount deficits, can be detrimental to the nation's economy.

2 Despite dramatic developments in recent years, the Turkish housing market suffers from several structural problems, such as declining affordability, limited access to mortgage finance and less developed mortgage insurance and secondary mortgage markets.

${ }^{3}$ FDI inflows into the real estate sector in Turkey have increased significantly, with almost USD 25 billion during 2004-2013 (RTME 2012; UNCTAD 2014). On the other hand, gradually increasing demand for residential property by foreigners in different parts of the country has also been observed.
} 
(2015) also indicates that strong structural demand from Turkey's young and growing population will remain the key driver of housing market activity.

Table 1 comparatively shows nominal/real housing price appreciation based on different indexes. According to the Central Bank of Turkey Housing Price Index (THPI) and the New Housing Price Index (TNHPI) ${ }^{4}$, housing prices have shown noteworthy real increases on the national level as well as in the regions of Istanbul, Ankara, Izmir, Adana and Antalya. For example, real housing price increases were respectively $34 \%$ and $68 \%$ in Turkey and in Istanbul according to THPI over the period between January 2010 and January 2015. Rapidly rising housing prices are not necessarily related to a bubble, but nevertheless bring about concerns. Moreover, implicit risks in the construction business (COSKUN 2013), rising vacancies 5 and declining affordability/confidence ${ }^{6}$ support the bubble concerns in the Turkish housing market.

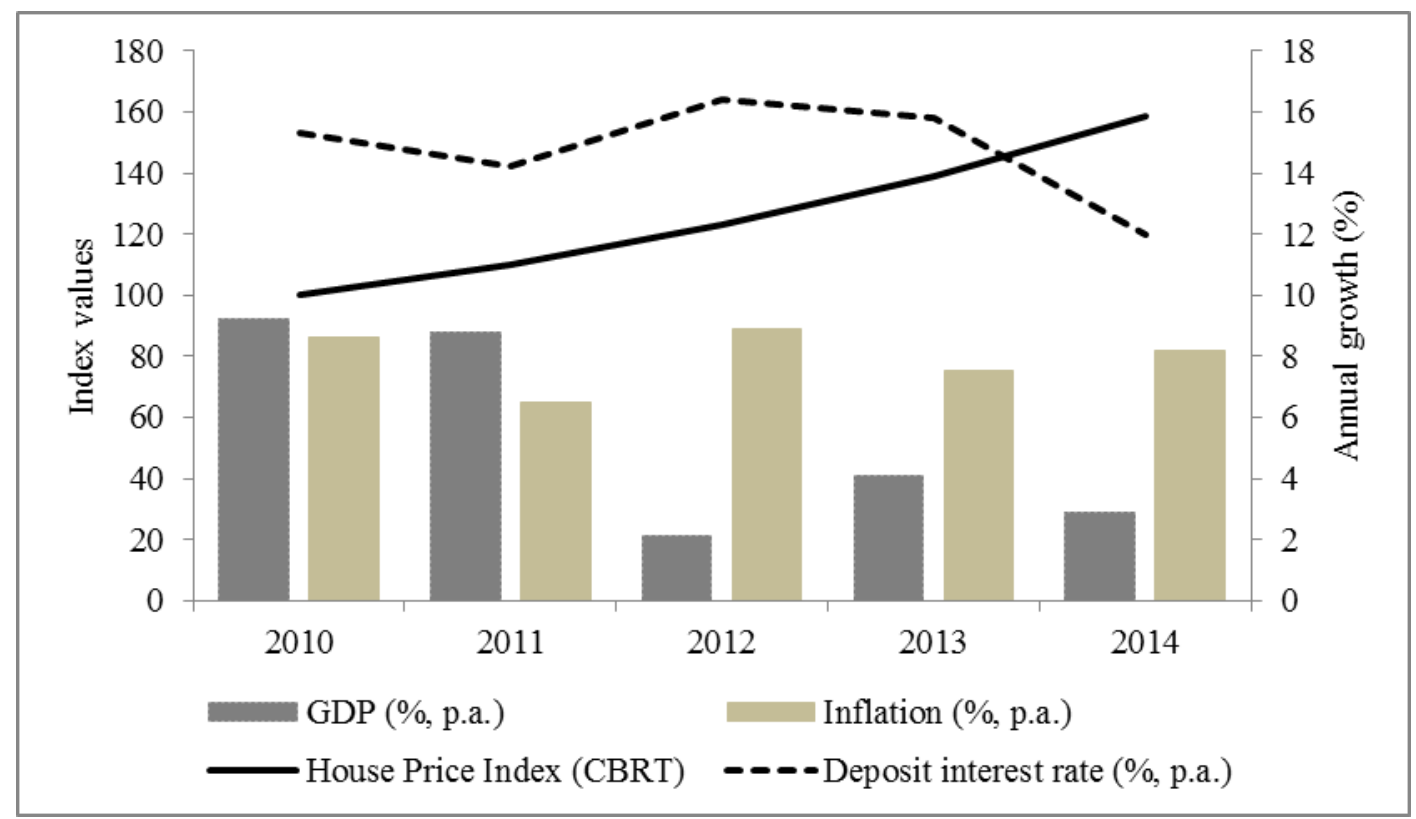

Abbreviations: CBRT: Central Bank of the Republic of Turkey (THPI Index).

Fig. 1. Selected series performance. Source: CBRT (2015); World Bank (2015).

Table 1

Nominal and Real Housing Price Growths in Turkey (Jan. 2008 - Jan. 2015; Jan. 2010 - Jan. 2015)

\begin{tabular}{lcccc}
\hline & & RHSPI (\%) & THPI $(\%)$ & TNHPI**(\%) \\
\hline ICPI (\%) & & 70 & 44 & 44 \\
\hline National & NI & 54 & 78 & 73 \\
\hline & RI & -16 & 34 & 29 \\
\hline Istanbul & NI & 68 & 112 & 112 \\
\hline & RI & -2 & 68 & 68 \\
\hline
\end{tabular}

\footnotetext{
${ }^{4}$ For methodological information on the THPI and TNHPI, see CBRT (2010).

${ }^{5}$ Even though there is no official data on the vacancy rate in the Turkish housing market, anecdotal evidence suggests that the number of vacancies (listed dwellings for sale) would be a sign of increasing housing market related risks. For example, the number of dwellings listed for sale on the Hurriyet Emlak and Milliyet Emlak websites, which are the largest online real estate brokerage channels in Turkey, are respectively 566,803 and 236,483 units as of June 6, 2016. Numerous media reports also suggest that the number of dwellings listed for sale is higher than the total of these figures (available on: http://www.hurriyetemlak. com/satilik-daire; http:// www.milliyetemlak.com/? gclid=CPmVmunqk s0CFfgW0 wodQ1YGaw, accessed on June 6, 2016).

${ }^{6}$ The construction confidence index dropped from 94.4 as of January 2011 to 82.3 as of July 2015. During the same period, construction price expectations for the next 3 months also declined from 113 to 106.2 (TURKSTAT 2015b).
} 


\begin{tabular}{lcccc}
\hline Ankara & NI & 42 & 57 & 64 \\
\hline Izmir & RI & -28 & 13 & 20 \\
\hline & NI & 52 & 69 & 73 \\
\hline $\begin{array}{l}\text { Adana; } \\
\text { TR62 }\end{array}$ & NI & -18 & 25 & 29 \\
\hline & RI & -5 & 83 & N/A \\
\hline $\begin{array}{l}\text { Antalya; } \\
\text { TR61 }\end{array}$ & NI & 19 & 39 & N/A \\
\hline & RI & -51 & 75 & N/A \\
\hline $\begin{array}{l}\text { Kocaeli; } \\
\text { TR42 }\end{array}$ & NI & 27 & 31 & N/A \\
\hline & RI & -43 & 50 & N/A \\
Bursa; TR41 & NI & 12 & 6 & N/A \\
\hline & RI & -58 & 49 & N/A \\
\hline
\end{tabular}

Abbreviations: RHSPI; Reidin House Sales Price Index (2008/Jan-2015/Jan), THPI: Central Bank of Turkey House Price Index (2010/Jan-2015/Jan), TNHPI; Central Bank of Turkey New Housing Price Index (2010/Jan-2015/Jan), ICPI: Increase in Consumer Price Index in relevant period, NI: nominal housing price increase, RI: Real housing price increase, $\mathrm{n}$ /a: not available. ${ }^{*}$ TR62 sub-index of THPI (TP.13TR62: TR 62) covering Adana and Mersin provinces. TR61 sub-index of THPI (TP.12TR61: TR 61) covering Antalya, Burdur and Isparta provinces. TR42 sub-index of THPI (TP.10TR42: TR 42) covering Bolu, Kocaeli, Sakarya, Yalova and Duzce provinces. TR 41 sub-index of THPI (TP.09TR41: TR 41) covering Bursa, Eskisehir, and Bilecik provinces. ${ }^{* *}$ There were no other provinces in the TNHPI index.

Source: REIDIN (2015); CBRT (2015) and authors' calculations.

\section{Literature Review}

\subsection{Theoretical, Empirical and Methodological Framework of a Housing Bubble}

Since trade and commerce began, commercial activities have been accompanied by financial crises and speculative bubbles (KINDLEBERGER 2001). As such, the existence of bubbles in business and the property market have been the subject of debate over centuries (HOYT 1933; BARLOWE 1958; ZARNOWITZ 1992; BARRAS 2009; BESOMI 2014; JADEVICIUS, HUSTON 2014) due to their pervasive nature and impact on economies and individual welfare (AKERLOF, SHILLER 2009; SHILLER 2006, 2012, 2013). Bubble analysis is critical due to various reasons. For example, the emergence of a bubble may signal that the economy already suffers from certain structural problems (BARLEVY 2007). The most obvious problem related to the bubble is the risk of economic slowdown as a result of housing busts, which have been shown to have a much stronger impact on the economy than stock busts (BLACK, FRASER and HOESLI 2006).

Three main characteristics of bubbles have been discussed in literature: momentum, explosiveness and intrinsicality (BLACK, FRASER and HOESLI 2006). Explosiveness and intrinsicality constitute the rational bubble theory which is grounded on an efficient market hypothesis and momentum denotes the general or irrational bubble theory (PITROS, ARAYICI 2016). In a rational bubble setting, an investor only holds a bubble asset if the bubble grows in expectations ad infinitum (BRUNNERMEIER 2016). Starting with SMITH, SUCHANEK and WILLIAMS (1988), many researchers document the existence of irrational bubbles in experimental financial markets. These bubbles are irrational in the sense that they would be ruled out by backward induction (MOINAS, POUGET 2013). As another dimension in bubble literature, REN, XIONG and YUAN (2012) discuss rational expectation bubbles, proposed by BLANCHARD and WATSON (1982), and static bubbles. Rational expectation bubbles are characterized by asset prices 
that continue to grow over time and returns that surpass the average capital return in the economy. If the economy has incomplete financial markets, static bubbles can exist in competitive equilibrium and allow entrepreneurs to re-allocate physical capital more efficiently. However, the bursting of static bubbles can generate large adverse welfare effects.

A bubble involves the purchase of an asset, usually real estate or a security, not because of the rate of return on the investment but in anticipation that the asset or security can be sold to someone else (to the "the greater fool" as the last buyer) at an even higher price (KINDLEBERGER, ALIBER 2005). According to CASE and SHILLER (2003), a bubble is a situation when the prices of an asset are temporarily elevated due to excessive public expectations regarding the future price of this asset. The superiority of speculative behavior and expectations of future capital gains over economic fundamentals were emphasized by KHOLDY and SOHRABIAN (1998). BRZEZICKA (2016) also argues that a speculative bubble is defined as an above-normal increase in property prices which is not justified by intrinsic factors. BAKER (2008) suggests that the dynamics of a bubble and crash are selfperpetuating. SHILLER (2014a) further suggested that a housing price bubble is a period when buyers are likely to acquire a house with the belief that they will be compensated by further price increases, regardless of the fact that their income may not cover the mortgage. For first time buyers, the bubble diminishes the fear of non-affordability pushing them to buy homes for any asking price. All this is precipitated by the rapid growth of housing prices. Therefore, a housing bubble involves significant price inflation with deviations from the fundamental value, which also results in overvaluations. AUGUSTYNIAK et al. (2013) argue that the residential real estate market shows cyclicality thanks to various demand- and supply-side factors. Statistically, as MAYER (2011) commented, a 20 per cent, 30 per cent, or even 40 per cent annual housing price growth over two or three years can signal a bubble. For example, BLACK, FRASER and HOESLI (2006) found the existence of an explosive rational bubble in the UK with 155\% nominal price inflation and 25\% overvaluation during the period 1997Q3-2004Q3. However, it is also important to note that sudden and significant housing price inflation is not, in itself, conclusive evidence of a bubble.

Bubble detection is essentially related to defining the determinants of housing prices as the main determinative factor of fundamental value. BJORKLUND and SODERBERG (1999) indicate that direct fundamental factors influencing prices in the real estate market are income, income growth and the required rate of return, while macroeconomic variables (i.e. interest rate, unemployment rate, GDP) indirectly affect real estate prices. CASE and SHILLER (2003) employed per capita income, population, employment, unemployment and mortgage interest rates over 1985-2000 as the fundamental variables for US housing bubble analysis. The study suggested no housing bubble, but fundamentals were at play in pushing US housing prices up since 1995, while speculative elements (expectations, senses of opportunity/urgency, excitement and the amount of over-optimistic talks) also inflated prices to even higher levels during this process.

The consent amongst economists is that market bubbles can be appreciated with the aid of robust analytics (SHILLER 2014a). MAYER (2011) suggests that the analysis of stylized facts and alternative factors, such as excess volatility, liquidity constrains and lending cycles, to name a few, can explain some of the variation of housing prices. However, because very few economists appreciated the most recent global housing bubble (GERARDI, FOOTE and WILLEN 2010), it is obvious that defining the bubble is a complex job. For example, WEISE, PHILIPS and HOCHHEIM (2015) suggest that a housing bubble can follow three different scenarios, i.e.: the bubble does not burst, or can burst with a slow decline or sudden and rapid collapse. The recent U.S. housing bubble was an interesting example to show how difficult it is to estimate a housing bubble. In this respect, while SHILLER (2005), KRUGMAN (2005) and STIGLITZ (2007) argued that the US housing market is obviously in a bubble, SMITH and SMITH (2006, p. 2) dismissed the claim and suggested two years before the crisis that "buying a home at current market prices still appears to be an attractive long-term investment". Similarly, HIMMELBERG, MAYER and SINAI's (2005) study did not find US housing to be overvalued. Still, subsequent events in the US and throughout the world turned out to be just the opposite, i.e. leading into the "worst financial and housing crisis since the Great Depression" (MAYER 2011).

In addition to definitions and roots of housing bubbles, there have been extensive debates as regards their detection. Various models are employed for bubble analysis, including ones involving affordability analyses and regression models which are used in this study. Affordability ratios, housing price-to-income and housing price-to-rent may suggest unaffordability in housing prices relative to income or rent as the fundamentals, and hence, would be a sign of overvaluation or a 
bubble. Therefore, affordability ratios may provide initial observations for bubble analysis as discussed by, among others, CASE and SHILLER (2003), DOLPHIN and GRIFFITH (2011), and TSAI (2013). However, it is equally important to note that affordability ratios may present only indicative knowledge on the bubble (OECD 2005; HLAVÁČEK, KOMÁREK 2009). Ratio analyses have several shortcomings. For example, calculating income is generally problematic, while average rent/price series can mask market polarization. AMBROSE, EICHHOLTZ and LINDENTHAL (2013) note that while the rent-price ratio is a measure of housing prices relative to fundamentals, it does not give a complete picture of the housing market. SMITH and SMITH (2006: 7) propose that price-rent ratios in the housing market can rise without signaling a bubble if, for example, interest rates fall, or the anticipated rate of increase in rent rises. HIMMELBERG, MAYER and SINAI (2005) suggest that by only comparing price-toincome and price-to-rent ratios, without accounting for changes in real long-term interest rates, expected inflation, expected housing price appreciation and taxes, one cannot accurately assess whether houses are reasonably priced. CAMERON, MUELLBAUER and MURPHY (2006: 2) also indicate that ratio analyses for housing price bubbles are not very informative about the presence/absence of bubbles because they ignore a range of other important factors, including demographic and population changes, house-building, credit conditions, and other asset prices. Therefore, systematic and comprehensive models are needed to assess bubbles.

On the other hand, despite raised concerns regarding the methodology (i.e. SHILLER 1992; SMITH, SMITH 2006), literature involves several studies employing regression models as an alternative bubble detection mechanism, e.g.: CASE and SHILLER (2003); SHEN, HUI and LiU (2005); BLACK, FRASER and HOESLI (2006); GLINDRO et al. (2011); AGNELLO and SCHUKNECHT (2011), and JOEBGES, DULLIEN and MÁRQUEZ-VELÁZQUEZ (2015). There is well-established literature that has examined the determinants of housing prices and bubbles. Empirical literature reveals that several housing market variables are employed as the demand and supply side variables in housing bubble analysis, such as mortgage rates, construction cost, housing supply and demand indicators, income, population and (un)employment. Moreover, macroeconomic and financial market related variables, such as CPI and money supply, are also employed due to their interactions with the housing market.

Literature also reveals that the bubble may be connected with explosive behaviors in asset prices. CASPI (2016) discusses that the theory predicts that if a bubble exists, prices should inherit its explosiveness property. This in turn enables formulating statistical tests aimed at detecting evidence of explosiveness in the data. In this context, PHILLIPS, WU and YU (2011) (henceforth PWY) developed a different bubble measurement strategy based on recursive and rolling ADF unit root tests. It is reported in the PWY's work that their test procedure is shown to have discriminatory power in detecting periodically collapsing bubbles, thereby overcoming a weakness in earlier applications of unit root tests for economic bubbles. HOMM and BREITUNG (2012) follow PWY more closely. Their sequential Chow-type DF test and the supDF test of PWY indicate explosive behavior in the US, UK, and Spanish housing price indices prior to the subprime crisis. PHILLIPS, SHI and YU (2015) (henceforth PSY) apply both SADF and GSADF tests, the sequential PWY dating algorithm, and the CUSUM (cumulative sum) monitoring procedure, along with their date-stamping algorithms, to the S\&P 500 price-dividend ratio from January 1871 to December 2010. They found that all four tests provided confirmatory evidence of the existence of multiple bubbles.

\subsection{Housing bubble debate in emerging economies}

As observed recently, property prices may rise faster across leading emerging countries than in developed ones. Therefore, Turkey is not the only middle-income emerging country which is on the watch of housing bubble analysts. The other two most notable housing markets are China and Brazil.

Utilizing granger causality and vector auto-regression (VAR) models over the period of 1999:Q22009:Q3 for China's residential market, MALLICK and MAHALIK (2012) found that speculative factors reflected by past increases in real housing prices contribute a relatively more to housing price rises as compared to fundamental factors. BARTH, LEA, and LI (2012) suggest that housing in China is unaffordable to an average individual despite the government's attempts to support home ownership, and too sharp of a pullback can lead to a price-collapse and financial instability. By applying the theory of rational expectation bubbles to 35 cities in China, REN, XIONG and YUAN (2012) find no evidence to support the existence of bubbles in the housing market. Housing unaffordability in China has also been commented on by FAWLEY and WEN (2013) and CHEN and WEN (2013). According to 
FAWLEY and WEN, housing prices in China are around 11 times the annual income. In the largest cities, such as Beijing and Shanghai, the price-to-income $(\mathrm{P} / \mathrm{E})$ ratio is close to 23 to 1 . CHEN and WEN's estimate suggests that, in both cities, $\mathrm{P} / \mathrm{E}$ ratios reached 30 to 1 and the vacancy rate stood at $30 \%$ or $\mathrm{m}$. The P/E ratio was 15 in Japan and 6 in the US when housing bubbles burst in 1990 and 2006, in both countries respectively. As such, FAWLEY and WEN suggested that rapid housing price inflation, high $\mathrm{P} / \mathrm{E}$ ratios, and high vacancy rates all indicate the possibility of a housing bubble in China. WANG and ZHANG (2014), however, suggest that changes in fundamental factors can account for a major proportion of the actual housing price appreciation for most of the Chinese cities; the actual increase in housing prices deviates largely from what can be predicted from fundamental changes in several coastal cities between 2002 and 2008. By employing an equilibrium asset-pricing approach for China, FENG and WU (2015) did not find the existence of a housing price bubble at the national level but also note that this conclusion depends greatly on the expected income growth rate, and may not apply to individual markets.

In terms of Brazil's housing market, a number of media outlets voiced some serious concerns about the state of the nation's residential real estate. SHILLER (2014b) also cautioned that speculative bubbles were also emerging in Brazil. SCHMIDT and CASTELLANI (2013) found that housing prices increased 220 per cent in Sao Paulo and 266 per cent in Rio, Brazil, since January 2008, as measured by the FIPE Zap index (FIPE ZAP 2013). A twofold increase compared to rent prices signaled that the housing market can be in a bubble. Housing prices in Brazil have recently corrected and the slowdown in housing prices appears to be gradual. However, overall prices continue to rise, which may imply overvaluations (WATSON 2014; ELOY, CLAUDIA 2014; RAPOZA 2015).

Much can be said and various facts collected to support and go against the bubble in China or Brazil. We could increase the number of emerging countries dealing with bubble concerns (i.e. India, Qatar), however such studies are very rare in the literature. In this respect, our study provides additional insight into the Turkish housing market in a timely way and represents an interesting case study, especially for other emerging markets.

\subsection{Housing bubble debate in Turkey}

The escalation of the property prices in Turkey is causing some commentators to suggest that housing prices may be out of touch with fundamentals. Media outlets (inter alia, REBUCCI 2014; FORBES 2014; THE NEW YORK TIMES 2014, THE FINANCIAL TIMES 2014, 2015) have pointed out the existence of a "price bubble" in the Turkish housing market. According to ROUBINI (2013), major urban centers in the country are in a bubble. Roubini emphasized fast-rising housing prices, high price-to-income ratios, and significant levels of mortgage debt as a percentage of household debt. ${ }^{7}$ He suggested that the Turkish housing bubble may not burst any time soon, but if macro-prudential policies are not altered, the outcome can prove "nasty". Echoing Roubini's remarks, the BANK FOR INTERNATIONAL SETTLEMENTS (2014) emphasized significant property price inflation in Turkey. Likewise, COSKUN, WATKINS and WHITE (2014) further commented that housing was not affordable on a national level in Turkey during the period of 2003-2012 based on the constructed housing price to income ratios and housing affordability index. ${ }^{8}$ REBUCCI (2015) and IMF (2015a) commented on housing disequilibrium in the country. More recently, MOODY's (2016) indicated that the rate of housing price growth in Turkey is not likely to be sustainable for much longer.

In contrary, the earliest study by BINAY and SALMAN (2008) did not find any evidence of a property price bubble in Turkey. The price to rent ratio, which the authors constructed, stood at around 18, a number below the world average. GEYIK (2012) suggested that an asset price bubble can potentially form, but not in any near future. KAYA et al. (2012), EMLAK KONUT GYO (2014) and FINANSINVEST (2014) did not see housing to be in a bubble either. In their recent market commentary, CUSHMAN \& WAKEFIELD (2014) further suggested that that traditional affordability measures such as price-to-rent and price-to-income did not indicate a bubble. For BUYUKDUMAN (2014), house price inflation was a natural reflection of changes in fundamentals. According to ZEREN and ERGUZEL'S (2015) estimates, neither Istanbul, nor Izmir or Ankara were in a bubble during January 2010 and June 2014. EROL

\footnotetext{
7 However, the official data and our calculations in section 5 reveal that price-to-income ratio and mortgage debts are not as significant as suggested by Roubini.

8 Difficulties in Turkish housing market have been also commented by COSKUN $(2011,2013)$ and YALÇINER and COSKUN (2014).
} 
(2015) did not find a housing price bubble in Turkey over the period of July 2007 and December 2012 either. Her overall hypothesis was that if housing prices continue to grow at the 2012 levels, it will take 6-7 years for a bubble to develop. KARASU (2015) suggests that the year 2012 can be argued as the beginning of the current housing market boom and a bubble may occur if this trend continues for several years. By employing the Bounds test, OLS/FMOLS/DOLS, the Kalman filter, and ARIMA models, COSKUN et al. (2017) provide evidence that the Turkish housing market has experienced some cases of overvaluation, but not bubble formation. As the only exception claiming a bubble in the Turkish housing market, PITROS, COSKUN and ARAYICI (2017) found that there was a serious housing bubble in the Turkish housing market by utilizing dating algorithms methodology, at least from 2011 up to 2015.

It is evident that there has been an ever-growing debate on bubble risk in the Turkish housing market over the last few years. What is surprising is the divergence in the presented opinions. On the one hand, international finance/media organizations are pointing to a bubble in the Turkish housing market. On the other hand, industry reports and rare academic studies do not see this to be the case, with one exception. The current study therefore puts greater clarity on the subject with formal housing bubble analysis.

\section{Empirical Strategy}

\subsection{Affordability ratio analysis}

As suggested in literature, high and steadily rising housing price-to-income (HPI) and housing priceto-rent (HPR) ratios would be an indicator of unaffordability, overvaluation and a bubble with careful evaluation and further support of more analytical techniques. In this context, the study initially employs annual/monthly HPI and monthly HPR series for Istanbul, Ankara, Izmir, and Turkey as a whole. To the best of the authors' knowledge, this is the first time when a monthly affordability series has been constructed in an academic study other than a private affordability index (see REIDIN 2015) for national/local housing markets in Turkey. Moreover, we also construct first-time aggregate/local level annual price-to-income ratios by utilizing province level income (GDP per capita) data.

In the case of HPI, the rule of thumb for defining the affordability (and over-/undervaluation) level is to compare an existing HPI ratio with its long-term averages. HPI (and HPR) thresholds may vary depending on the level of economic development and socio-economic structures of the analyzed countries or cities. In this respect, KARAMUJIC (2013) argues that the thresholds at which the housing market is perceived as unaffordable/overvalued vary. For example, GIROUARD et al. (2006) believe that if the ratio is above its long-term average (or 4-5), it is possible to assume that the housing market is overvalued and indicate a bubble. KOSAREVA and TUMANOV (2008) suggest that housing affordability ratio values of three to five are considered normal in international practice. MENGJIE, REED and WU (2008) underline that a ratio between 2 and 6 is generally considered to be acceptable. DEMOGRAPHIA (2015) classifies the housing market as "severely unaffordable" if the median multiple is equal to or over 5.1. Therefore, cautiously basing off the available literature, we may conclude that there is noteworthy unaffordability/overvaluation in a housing market if the HPI ratio is higher than the threshold of 5-6, signifying that the increase in average housing price is obviously higher than the increase in average income.

The ratio is estimated as follows:

$$
H P I_{t}=P_{t} / E_{t}
$$

where $P_{t}$ is the housing price and $E_{t}$ is the average income at the period of time $t$.

The HPR ratio is estimated as follows:

$$
H P R_{t}=P_{t} / R_{t}
$$

where $R_{t}$ is the average rent paid for a property at time period $t$.

The HPR ratio traditionally measures the cost of owning versus renting a property (OECD 2005; GIROUARD et al. 2006) and acts as an alternative housing market barometer (GALLIN 2008). Same as HPI, a high HPR generally indicates overvaluation, while a low one - undervaluation (BRAM 2012). According to TRULIA (2016), if the HPR ratio (i) is between 1 and 15, it is advisable to a buy property instead of renting; (ii) if HPR is between 16 and 20, it is better to rent than to buy; (iii) and if the ratio is 
above 21 , it is a clear sign to rent. However, high and rising HPR ratios may not necessarily signal a bubble but overvaluation, reflecting that housing prices have grown faster than rental values. The occurrence of large and long-lasting deviation in the price-rent ratio from its average value might be an initial sign of a bubble (see KRAINER, WEI 2004). Thus, similar to HPI, HPR analysis provides indicative information and should also be supported by more robust analytics.

\subsection{Regression analysis}

Because affordability ratios provide indicative information on a bubble, a series of linear regressions are computed as a more robust bubble detection methodology. Here, GDP per capita (income variable), population, employment, unemployment, housing starts and mortgage rates are examined as per CASE and SHILLER (2003).

Based simply on the relationship between housing prices and income, $H P_{t}$ is the housing price index value in period $t$, and $\boldsymbol{L}_{t}$ is the estimate of the average income in period $t$ in Equation 3.

$$
H P_{t}=\alpha+\beta_{1} I_{t}+e_{t}
$$

The same single-regressions are built for all six explanatory variables in Equation 4 where population $\left(P_{t}\right)$, employment $\left(E_{t}\right)$ and unemployment $\left(U_{t}\right)$ rate, housing starts $\left(H_{t}\right)$, and mortgage interest rate $\left(R_{t}\right)$ are all added to the equation.

$$
H P_{t}=\alpha+\beta_{1} I_{t}+\beta_{2} P_{t}+\beta_{3} E_{t}+\beta_{4} U_{t}+\beta_{5} H_{t}+\beta_{6} R_{t}+e_{t}
$$

To expand CASE and SHILLER's (2003) framework, we add eight new explanatory variables into Equation 5 based on the review of literature, namely construction costs $\left(\mathrm{CO}_{\mathrm{t}}\right)$, construction permits $\left(C P_{t}\right)$, housing credit $\left(H C_{t}\right)$, construction credit $\left(C C_{t}\right)$, GDP per capita $\left(G C_{t}\right)$, money supply (M2) $\left(M S_{t}\right)$, the stock market index $\left(S M_{\mathrm{t}}\right)$, and the inflation index $\left(I_{\mathrm{t}}\right)$.

$$
H P_{t}=\alpha+\beta_{1} C O_{t}+\beta_{2} C P_{t}+\beta_{3} H C_{t}+\beta_{4} C C_{t}+\beta_{5} G C_{t}+\beta_{6} M S_{t}+\beta_{7} S M_{t}+\beta_{9} I_{t}+e_{t}
$$

In addition to the above-noted regression specifications, the so-called Rtadf (Right Tail Augmented Dickey-Fuller) test is employed for further bubble analysis. The test consists of four variations of the right tail ADF unit root test, including (i) the standard ADF test, (ii) the rolling window ADF test, (iii) the PWY supremum ADF (SADF) test, (iv) and the PSY generalized SADF (GSADF) test (PHILLIPS, WU and YU 2011; CASPI 2013; PHILLIPS, SHI and YU 2015).

The econometric specification of the Rtadf test is as follows:

$$
y_{t}=\mu+\delta y_{t-1}+\sum_{i=1}^{p} \phi_{i} \Delta y_{t-1}+\epsilon_{t}
$$

where $y_{t}$ is the dependent variable (housing series for Turkey, Istanbul, Ankara and Izmir), $\mu$ is the regression intercept, $p$ is the maximum number of lags, $\phi_{i}$ differenced lag coefficients, and $\varepsilon_{t}$ is an error term. The null-hypothesis assumes a unit root, while an alternative hypothesis rejects it.

\subsection{Data}

To calculate HPI and HPR, we first construct a monthly housing price series for Istanbul, Ankara, Izmir, and Turkey by using housing price per square meter series and average floor area data provided by the Central Bank of the Republic of Turkey (CBRT) (2015) and TURKSTAT, respectively. Monthly rental prices for existing homes were obtained from REIDIN (2015). Because city level monthly income series were not available, we utilized the national aggregate for constructing the income variable in the monthly HPI. In this respect, GDP per capita was used both as the average income variable in monthly HPI ratios of Istanbul, Ankara, and Izmir, and an independent variable in the classical/extended CASE and SHILLER regression models. By using the industrial production index as the proxy and following FERNÁNDEZ (1981) and KARA and ÖĞÜNÇ (2012) methodology, quarterly Turkish Lira denominated - GDP series were transformed into monthly ones. Determined by dividing the constructed monthly GDP to population, monthly GDP per capita series were converted to USD to make the series less volatile. Quarterly GDP, the industrial production index, and the Turkish Lira/USD exchange rate are provided by CBRT (2015). 
It is important to note that, according to TURKSTAT (2016) province level annual income data, GDP per capita in Istanbul, Ankara, and Izmir have respectively shown $66 \%$, 43\% and $17 \%$ higher average values when compared to annual national GDP per capita during 2010-2014. Because (constructed) monthly and annual income series have different dynamics due to their different methodologies, we also calculated annual HPI ratios based on USD denominated GDP per capita for Istanbul, Ankara and Izmir. Annual HPI ratios may provide a more realistic picture thanks to reflecting local nuances. The Turkish Lira denominated province level annual income dataset was retrieved from TurkStat and converted into USD utilizing CBRT exchange rates.

To adopt CASE and SHILLER's (2003) framework, population, employment rate, unemployment rate, and housing starts series came from TURKSTAT (2015a). CBRT (2015) provided mortgage interest rate and housing price index series (THPI). Table $2 \mathrm{a}$ reports the summary statistics of the series. To expand CASE and SHILLER's (2003) framework, we additionally utilize the following variables and data sources: construction costs and construction permits (from TURKSTAT); housing credit and construction credit (from the Banking Regulation and Supervision Agency of Turkey); money supply (M2), stock market index and inflation index (CPI) (from CBRT). Quarterly construction cost series were transformed to monthly series by employing the cubic spline interpolation method. Table $2 \mathrm{~b}$ reports the summary statistics of these series.

Series summary statistics for Case-Shiller Framework (Jan. 2010 - Dec. 2014)

Table 2a

\begin{tabular}{|c|c|c|c|c|c|c|c|}
\hline \multirow[t]{2}{*}{ Selected series } & \multicolumn{7}{|c|}{ Summary statistics } \\
\hline & Mean & St. Dev. & Kurtosis & Skew. & Min. & Max. & $\mathrm{N}$ \\
\hline $\begin{array}{l}\text { Housing price } \\
\text { index }\end{array}$ & 126 & 21.54 & -0.96 & 0.42 & 96.92 & 169.99 & 60 \\
\hline Turkey & 114 & 20.48 & -0.95 & 0.59 & 91.33 & 157.07 & 60 \\
\hline Ankara & 108 & 15.38 & -1.22 & 0.36 & 88.40 & 137.24 & 60 \\
\hline Istanbul & 118 & 25.63 & -0.80 & 0.67 & 88.82 & 173.16 & 60 \\
\hline Izmir & 117 & 18.19 & -1.31 & 0.37 & 96.63 & 151.70 & 60 \\
\hline $\begin{array}{l}\text { House rent } \\
\text { index }\end{array}$ & & & & & & & \\
\hline Turkey & 108 & 15.88 & -0.89 & 0.57 & 90.03 & 142.04 & 60 \\
\hline Ankara & 106 & 12.86 & -1.15 & 0.45 & 91.82 & 130.51 & 60 \\
\hline Istanbul & 111 & 18.54 & -0.72 & 0.66 & 89.40 & 151.77 & 60 \\
\hline Izmir & 106 & 16.10 & -1.33 & 0.32 & 87.35 & 136.27 & 60 \\
\hline Income & 9789 & 600 & -0.35 & -0.65 & 8423 & 10604 & 60 \\
\hline Population & $75,687,682$ & $1,410,772$ & -1.29 & 0.04 & $73,722,988$ & $77,695,904$ & 60 \\
\hline Employment & 18,634 & 1,306 & -1.10 & -0.06 & 16,373 & 20,791 & 60 \\
\hline Unemployment & 12 & 1.50 & 1.80 & 1.12 & 9.10 & 16.30 & 60 \\
\hline Housing starts & $6,058,289$ & $2,321,091$ & 5.03 & 1.73 & $2,819,498$ & $15,941,336$ & 60 \\
\hline Mortgage rate & 11 & 1.48 & -0.47 & 0.30 & 8.48 & 14.49 & 60 \\
\hline
\end{tabular}

Table 2/b

Series summary statistics for expanded Case-Shiller Framework (Jan. 2010 - Dec. 2014)

Selected series

Summary statistics 


\begin{tabular}{|c|c|c|c|c|c|c|c|}
\hline & Mean & St. Dev. & Kurtosis & Skew. & Min. & Max. & $\mathrm{N}$ \\
\hline $\begin{array}{l}\text { Construction } \\
\text { costs }\end{array}$ & 118 & 12.45 & -0.81 & 0.05 & 98 & 139 & 58 \\
\hline $\begin{array}{l}\text { Construction } \\
\text { permits }\end{array}$ & $9,111,118$ & $5,284,165.32$ & 19.25 & 3.76 & $3,639,677$ & $39,735,330$ & 60 \\
\hline Housing credit & 68,450 & $12,833.71$ & -0.94 & -0.21 & 43,419 & 89,170 & 60 \\
\hline $\begin{array}{l}\text { Construction } \\
\text { credit }\end{array}$ & 41,677 & $11,525.18$ & -1.05 & 0.50 & 24,824 & 63,360 & 60 \\
\hline Income & 9,789 & 600.42 & -0.35 & -0.65 & 8,423 & 10,604 & 60 \\
\hline $\begin{array}{l}\text { Money supply } \\
\text { (M2) }\end{array}$ & 610,790 & $61,985.32$ & -0.87 & 0.03 & 497,917 & 722,553 & 60 \\
\hline $\begin{array}{l}\text { Stock market } \\
\text { index }\end{array}$ & 57,367 & $5,764.03$ & -0.37 & -0.05 & 44,972 & 69,161 & 60 \\
\hline Inflation index & 118 & 13.20 & -1.21 & 0.20 & 99 & 141 & 60 \\
\hline
\end{tabular}

Source: CBRT (2015); REIDIN (2015); TURKSTAT (2015a); BRSA and authors' calculations.

\section{Empirical Estimates}

\subsection{Affordability ratios}

\subsubsection{House Price to Income ratio (HPI)}

Fig. 2 shows the comparison among monthly constructed HPI ratios for Ankara, Istanbul, Izmir and Turkey, and GDP per capita in terms of USD, implying interesting housing market characteristics. First, the overall estimates for HPI ratios are not as high as perceived by the media. They stood at 9.3, 6.2, 7.3 and 6.8 for Istanbul, Ankara, Izmir and Turkey respectively, for December 2014. Moreover, as estimates suggest for the period of 2010-2014, the average HPI ratios for Istanbul, Ankara, Izmir and Turkey stood at 8.5, 6.3, 7.1 and 6.6 respectively. ${ }^{9}$ Ratios also did not deviate much over the sample period. On the other hand, annually constructed HPI ratios, involving local income data, suggest lower HPI values, specifically in the case of Istanbul. In this respect, annual HPI ratios are as follows: Istanbul $(5.2 ; 4.8 ; 4.6 ; 4.3 ; 5.1)$, Ankara $(4.1 ; 3.9 ; 4.0 ; 3.9 ; 4.0)$, Izmir $(6.1 ; 5.6 ; 5.5 ; 5.3 ; 5.6)$ and Turkey $(6.6$; 6.2; 6.0; 5.7; 6.2) respectively for the period between 2010 and 2014. Therefore, while monthly constructed HPI ratios are above traditionally accepted affordability benchmarks and suggest that the analyzed housing markets are unaffordable/overvalued, annual HPI ratios generally suggest no explosive HPI trends in local/national markets during the period of observation (see 4.1).

We cannot compare existing HPI ratios with their historical averages due to the lack of housing price and hence HPI data for the Turkish housing market. However, HPI for Turkey is lower than in other emerging and Western economies. For example, the P/E ratio for Beijing, Hong Kong and Shanghai is approaching 30. It is around 13 for Britain, 12 for the Netherlands and 9 for the US (NuMBEO 2015; The ECONOMIST 2015). DeMOGRAPHIA (2015) suggests that Australia, New Zealand and Hong Kong are severely unaffordable with median multiples of 6.4, 9.7, and 19.0, respectively. The study also suggests that Sydney, Vancouver, and Melbourne are severely unaffordable cities with 12.2, 10.8 and 9.7 median multiples respectively. Therefore, despite the mixed results in annually/monthly constructed HPI ratios and monthly HPI ratios suggesting overvaluations in the national/local markets, it is still early for a bubble formation due to the lack of dramatic movements in housing prices and income.

\footnotetext{
9 There are some industry reports analyzing HPI for Turkey and Istanbul. CUSHMAN and WAKEFIELD (2014: 3) suggests that the average value of a house is equal to the sum of the average annual income of 6.5-7 years in Turkey. Based on quarterly data, HALK YATIRIM (2015:3) suggests that the trend in the housing price to income ratio does not suggest a price bubble for Istanbul during 2003-2014. For the annual HPI trend, also see COSKUN, WATKINS and WHITE (2014).
} 
Secondly, the increase in USD denominated GDP per capita was higher than the increase in aggregate/local level housing price inflations over the 2010-2014 period. Thus, the case of Turkey generally seems parallel to the framework described in FOX and TULIP (2014). In this respect, as income (and hence the demand for housing) grows, prices (and rents) increase in Turkey during the observation period..$^{10}$ Because demand for housing is price-inelastic, prices need to rise faster than incomes to keep demand in line with supply. All other things being equal, this suggests that housing price growth may also reflect an increase in national prosperity rather than market speculation during the period between 2010 and 2014. Thirdly, however, a more recent May 2014-to-December 2014 subperiod in the monthly constructed income series saw a divergence from this trend. Housing prices appreciated more compared to GDP in the TL-dominated monthly income series, with the exception of Ankara. This divergence can therefore be a signal of a possible speculative component in the market.

Therefore, initial estimates demonstrate that annually constructed HPI ratios are generally lower, and monthly constructed HPI ratios are higher than the overvaluation benchmark in the housing markets of Istanbul, Ankara, Izmir and Turkey. Because the latter result should be evaluated carefully due to methodological concerns, we may argue that both HPI series suggest no bubble formation. As noted above, the evidence is in support of rational housing price growth which is likely to be advancing due to growing national income and overall wealth rather than market externalities observed over the period of 2010-2014, though the situation may change if the current trend of the widening gap between average income and housing prices continues.

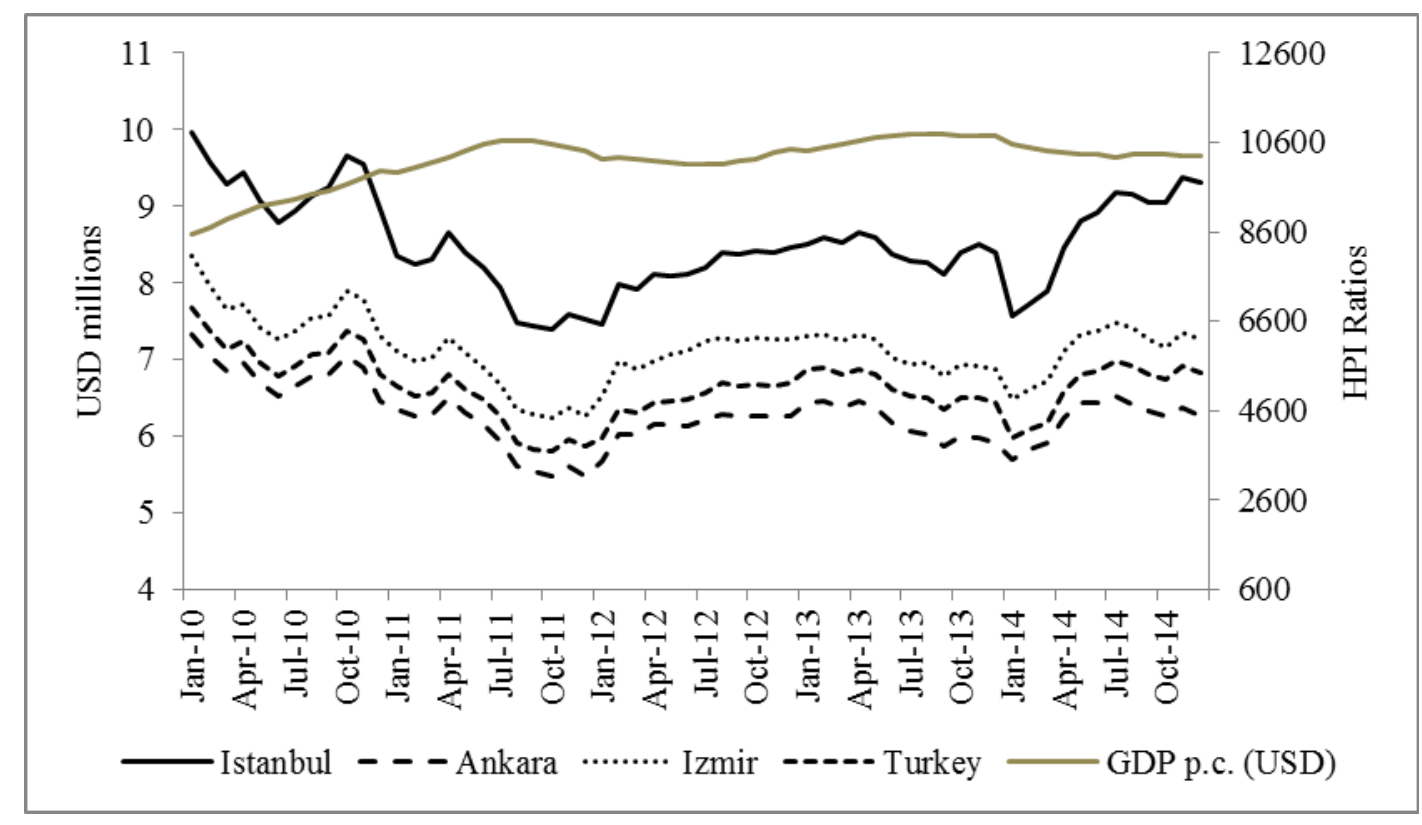

Fig. 2. National GDP per-capita and HPI Ratios for Istanbul, Ankara, Izmir and Turkey. Source: CBRT (2015) and authors' calculations.

\subsubsection{Housing Price to Rent Ratio (HPR)}

The analysis of the HPR series provides further insights into the Turkish housing market (Fig. 3). As estimates suggest, the average HPR ratios for Istanbul, Ankara, Izmir and Turkey were 17.9, 18.3, 17.9, and 14.8 respectively during the period 2010-2014. HPR ratios stood at 19.5, 18.9, 18.5 and 15.1 in December 2014, for Istanbul, Ankara, Izmir, and Turkey, respectively. Moreover, the highest HPR ratios stood at 19.5, 19, 18.7, and 15.3 (on different dates) respectively; the difference between the highest and the lowest HPR ratios were 3.2; 2.2; 1.9 and 1.6 for Istanbul, Ankara, Izmir and Turkey during the period under analysis.

\footnotetext{
${ }^{10}$ It is also important to note that volatile but gradually declining interest rate over the period of observation also probably played a role in rising demand for housing and prices.
} 
We cannot compare the constructed HPR ratio and its historical averages due to lack of housing price and rent data. Nevertheless, HPR series suggest three interesting points. Firstly, even though decision-making is rather disputable due to constraints in HPR methodology, particularly average HPR ratios generally suggest not to buy a property (better to rent) in the analyzed housing markets. It may be interesting to note that IMF $(2015 b)$ also suggests that the HPR ratio for Turkey is the highest as of September 2015 when compared to selected advanced/emerging countries, such as: New Zealand, Germany, Sweden, Israel, Norway, Mexico, etc. From the perspective of bubble analysis, HPR ratios may suggest overvaluation in the analyzed national/local housing markets. However, it may still be too early for bubble formation due to the lack of more dramatic/explosive movements in the housing price and rent series.

Next, while income series have been declining, local level HPR ratios showed different patterns during 2014. For example, while HPR was almost unchanged in the national housing market, the Istanbul housing market experienced an increase. Thirdly, housing price growth outpaced rental growth, especially in big cities such as Istanbul, Ankara and Izmir. This trend has become particularly apparent following the late 2012 and early 2013 period in all TL/USD denominated HPR series. This may suggest that rental affordability has been declining and also that households push house prices upwards due to the conviction that home ownership is a better investment or purchase option over tenancy. However, it may be interesting to speculate that the pattern of higher increases in housing prices as compared to rental values suggests that housing investment may not be rational from the asset management perspective.

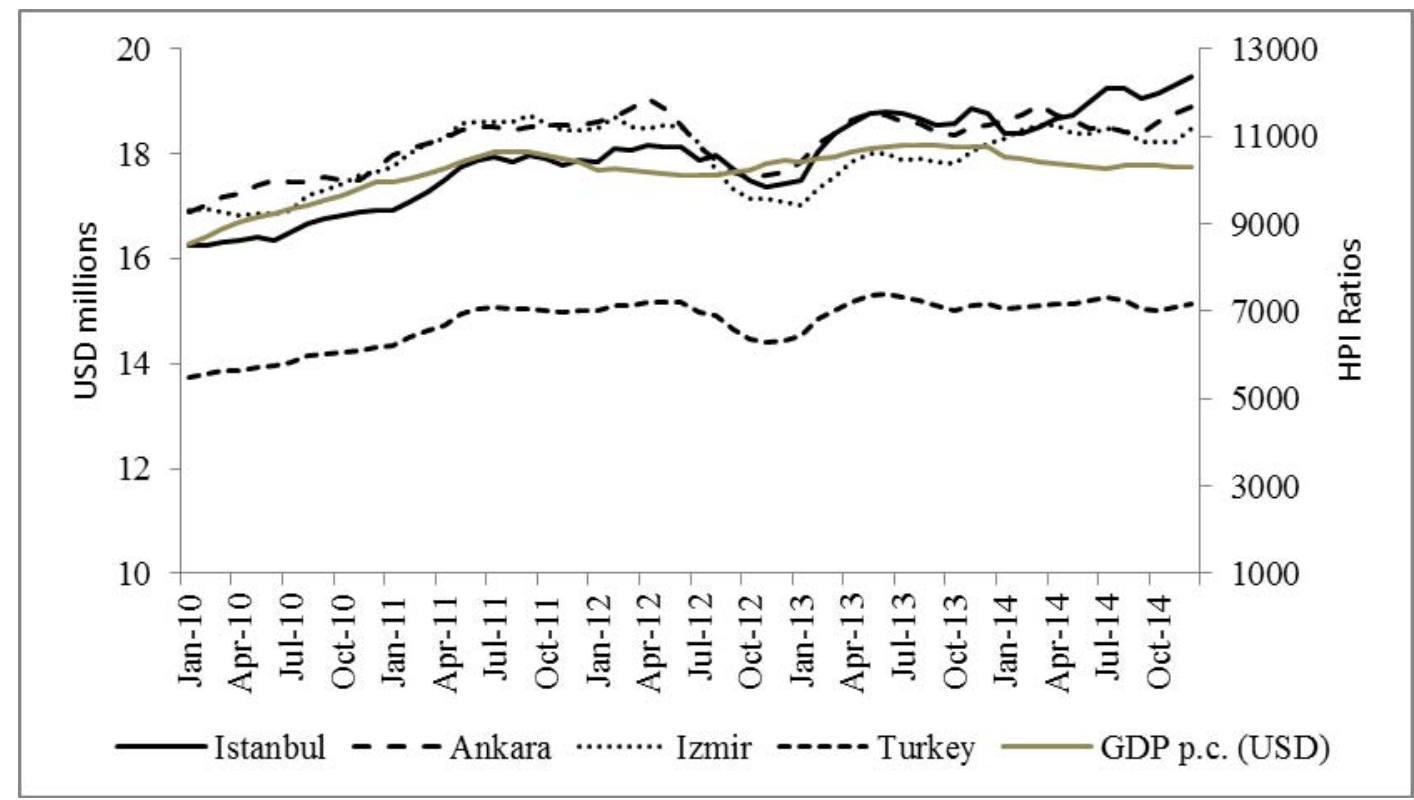

Fig. 3. National GDP per-capita and HPR Ratios of Istanbul, Ankara, Izmir and Turkey Source: CBRT (2015); Reidin (2015) and authors' calculations.

In summary, particularly HPR ratios may suggest that overvaluation in housing prices may be a signal of bubble formation. Macroeconomic (i.e. housing-market oriented growth policies, low interest rates) and housing market related (i.e. over-demand, rent-seeking and strong investment motives of households/investors) factors may play a role in this market structure. However, the lack of dramatic/persistent/explosive movements in housing prices, rent, and income series may suggest that this formation may not be strong or may be in its early period. Thus, combined with HPI and HPR analyses, we may conclude that affordability ratios indicatively suggest that Istanbul, Ankara, Izmir and the national housing markets were not in a bubble during the period from 2010 to 2014.

\subsection{Regression Analysis}

\subsubsection{Case and Shiller Framework}

To adapt CASE and SHILLER's (2003) framework for the Turkish housing market, the study uses seven series. These are the Central Bank of Turkey housing price indices (national/city level THPI 
indexes), income (GDP per capita), population, employment rate, unemployment rate, housing starts and mortgage rate. All series were tested for stationary. Unit-root tests results have been presented in Table 3. The need for multiple testing comes from BROOKS and TSOLACOS (2010) and CANARELLA, MILLER and POLLARD (2012). As suggested, there are a number of limitations related to a single unit-root testing approach. As such, four popular tests were employed. Once series satisfied the stationary requirement, the models were estimated.

Table 4 presents regression estimates. Equations were modified with the NEWEY-WEST (1987) estimator to remove instances of autocorrelation and heteroskedasticity of the error terms. Additionally, the Breusch-Godfrey test for serial correlation in the residuals was performed. Where needed, equations were further modified by introducing the AR (p) term to take additional account of serial correlation.

Table 3

Unit-root test results for Case-Shiller framework

\begin{tabular}{lcccr}
\hline & \multicolumn{3}{c}{ Test results for selected series } \\
\cline { 2 - 5 } Series & ADF & DF-GLS & PP & KPSS \\
\hline Housing prices (Ankara) & 1.735 & 1.086 & 2.654 & 0.958 \\
\hline Housing prices (Ankara) (1-dif) & -4.633 & -4.118 & -4.624 & 0.572 \\
\hline Housing prices (Istanbul) & 10.206 & 0.465 & 12.925 & 0.934 \\
\hline Housing prices (Istanbul) (1-dif) & -1.873 & -0.008 & -3.171 & 0.940 \\
\hline Housing prices (Izmir) & 3.280 & -0.106 & 4.093 & 0.956 \\
\hline Housing prices (Izmir) (1-dif) & -5.457 & -0.457 & -5.438 & 0.941 \\
\hline Housing prices (Turkey) & 3.686 & 0.498 & 7.043 & 0.953 \\
\hline Housing price (Turkey) (1-dif) & -3.309 & -2.331 & -3.150 & 0.874 \\
\hline Income & -2.005 & -0.042 & -3.609 & 0.912 \\
\hline Income (1-dif) & -1.519 & -1.397 & -3.811 & 0.532 \\
\hline Income (2-dif) & -6.569 & -1.040 & -18.598 & 0.178 \\
\hline Population & -0.671 & 0.450 & -0.538 & 0.942 \\
\hline Population (1-dif) & -36.485 & -7.940 & -8.287 & 0.061 \\
\hline Employment & -1.014 & 0.939 & -1.629 & 0.961 \\
\hline Employment (1-dif) & -7.520 & -6.711 & -7.925 & 0.216 \\
\hline Unemployment & -1.492 & -0.707 & -2.820 & 0.414 \\
\hline Unemployment (1-dif) & -4.045 & -4.037 & -3.539 & 0.457 \\
\hline Housing starts & -2.765 & -1.460 & -2.339 & 0.940 \\
\hline Housing starts (1-dif) & -7.632 & -8.011 & -16.001 & 0.096 \\
\hline Mortgage rate & -2.689 & -2.587 & -1.986 & 0.072 \\
\hline Mortgage rate (1-dif) & -3.990 & -3.862 & -3.829 & 0.071 \\
\hline Hor & & & \\
\hline
\end{tabular}

Note: Test critical values (significance at the level of 5 per cent) are as follows:

1) Augmented Dickey-Fuller (ADF) test: -2.912;

2) Dickey-Fuller (DF)- GLS (ERS) test: -1.947 ;

3) Phillips-Peron (PP) test: -2.912;

4) Kwiatkowski-Phillips-Schmidt-Shin (KPSS) test: 0.463;

${ }_{1}^{1}$ MacKinnon (1991, p. 275)

${ }^{2}$ Kwiatkowski, et al. (1992, p. 166) 
When comparing current estimates with CASE and SHILLER's (2003) findings for the US, some interesting similarities emerge. As in the American study, single-regression equations explain around 50 per cent of deviation in the national housing market. Employment, housing starts and population emerged as the key explanatory variables. The model containing all 5 variables improves model fit to 70 per cent, suggesting that a large proportion of national housing series can be attributed to fundamentals as per the Case/Shiller framework.

The explanatory power of these variables, however, diminishes in Ankara and Izmir. Singlevariable based model fit does not advance above 30 per cent indicating that a more granular (city level if possible) series should be employed for these cities. Interestingly, Istanbul modelling estimates relate more to national rather than regional results. Single-variable based models explained around 50 per cent of the housing prices in the city. All-variable model fit is close to two-thirds of the pricing levels. This potential homogeneity between the national and Istanbul housing modelling estimates is likely to come from Istanbul's dominance. The city, with its strategic location, is the commercial, cultural and historical center, and the most populous city in the country. These are, therefore, the likely reasons as to why Istanbul's housing market reflects the dynamics of the overall national market better than any other city in Turkey.

Table 4

Regression estimates for Case-Shiller framework

\begin{tabular}{|c|c|c|c|c|}
\hline Independent variables & Coefficient & R-sq. & B-G test & $\mathrm{AR}(\mathrm{p})$ \\
\hline \multicolumn{5}{|l|}{ Ankara } \\
\hline \multirow[t]{2}{*}{ Income } & 0.002 & 0.245 & 0.006 & $\mathrm{AR}(1)$ \\
\hline & $(0.108)$ & & $(0.938)$ & \\
\hline \multirow[t]{2}{*}{ Employment } & 0.000 & 0.205 & 0.108 & $\mathrm{AR}(1)$ \\
\hline & $(0.775)$ & & $(0.742)$ & \\
\hline \multirow[t]{2}{*}{ Housing starts } & 0.000 & 0.210 & 0.059 & $\mathrm{AR}(1)$ \\
\hline & $(0.587)$ & & $(0.809)$ & \\
\hline \multirow[t]{2}{*}{ Population } & 0.000 & 0.204 & 0.110 & $\mathrm{AR}(1)$ \\
\hline & $(0.966)$ & & $(0.740)$ & \\
\hline \multirow[t]{2}{*}{ Mortgage rate } & -0.107 & 0.213 & 0.105 & $\mathrm{AR}(1)$ \\
\hline & $(0.342)$ & & $(0.746)$ & \\
\hline \multirow[t]{2}{*}{ Unemployment } & -0.092 & 0.210 & 0.350 & $\mathrm{AR}(1)$ \\
\hline & $(0.545)$ & & $(0.554)$ & \\
\hline \multirow[t]{2}{*}{5 variables (ex-Income) } & & 0.268 & 0.154 & $\mathrm{AR}(1)$ \\
\hline & & & $(0.695)$ & \\
\hline \multicolumn{5}{|l|}{ Istanbul } \\
\hline \multirow[t]{2}{*}{ Income } & 0.002 & 0.479 & 1.512 & $\mathrm{AR}(2)$ \\
\hline & $(0.402)$ & & $(0.219)$ & \\
\hline \multirow[t]{2}{*}{ Employment } & -0.003 & 0.551 & 2.108 & $\mathrm{AR}(2)$ \\
\hline & $(0.008)$ & & $(0.147)$ & \\
\hline \multirow[t]{2}{*}{ Housing starts } & 0.000 & 0.489 & 0.990 & $\mathrm{AR}(2)$ \\
\hline & $(0.241)$ & & $(0.320)$ & \\
\hline Population & 0.000 & 0.504 & 1.411 & $\mathrm{AR}(2)$ \\
\hline
\end{tabular}




\begin{tabular}{|c|c|c|c|c|}
\hline & $(0.022)$ & & $(0.235)$ & \\
\hline \multirow[t]{2}{*}{ Mortgage rate } & -0.354 & 0.507 & 2.892 & $\mathrm{AR}(2)$ \\
\hline & $(0.103)$ & & $(0.089)$ & \\
\hline \multirow[t]{2}{*}{ Unemployment } & -0.286 & 0.500 & 1.596 & $\mathrm{AR}(2)$ \\
\hline & $(0.148)$ & & $(0.206)$ & \\
\hline \multirow[t]{2}{*}{5 variables (ex-Income) } & & 0.630 & 4.057 & $\mathrm{AR}(2)$ \\
\hline & & & $(0.044)$ & \\
\hline \multicolumn{5}{|l|}{ Izmir } \\
\hline \multirow[t]{2}{*}{ Income } & 0.000 & 0.094 & 0.011 & $\mathrm{AR}(1)$ \\
\hline & $(0.759)$ & & $(0.915)$ & \\
\hline \multirow[t]{2}{*}{ Employment } & -0.002 & 0.188 & 0.146 & $\mathrm{AR}(1)$ \\
\hline & $(0.053)$ & & $(0.702)$ & \\
\hline \multirow[t]{2}{*}{ Housing starts } & 0.000 & 0.126 & 0.102 & $\mathrm{AR}(1)$ \\
\hline & $(0.699)$ & & $(0.749)$ & \\
\hline \multirow[t]{2}{*}{ Population } & 0.000 & 0.152 & 0.016 & $\mathrm{AR}(1)$ \\
\hline & $(0.260)$ & & $(0.900)$ & \\
\hline \multirow[t]{2}{*}{ Mortgage rate } & -0.237 & 0.150 & 0.166 & $\mathrm{AR}(1)$ \\
\hline & $(0.158)$ & & $(0.684)$ & \\
\hline \multirow[t]{2}{*}{ Unemployment } & 0.067 & 0.127 & 0.037 & $\mathrm{AR}(1)$ \\
\hline & $(0.734)$ & & $(0.847)$ & \\
\hline \multirow[t]{2}{*}{5 variables (ex-Income) } & & 0.192 & 0.225 & $\mathrm{AR}(1)$ \\
\hline & & & $(0.635)$ & \\
\hline \multicolumn{5}{|l|}{ Turkey } \\
\hline \multirow[t]{2}{*}{ Income } & 0.001 & 0.487 & 2.515 & $\mathrm{AR}(1)$ \\
\hline & $(0.337)$ & & $(0.113)$ & \\
\hline \multirow[t]{2}{*}{ Employment } & -0.002 & 0.586 & 3.609 & $\mathrm{AR}(1)$ \\
\hline & $(0.001)$ & & $(0.058)$ & \\
\hline \multirow[t]{2}{*}{ Housing starts } & 0.000 & 0.511 & 2.435 & $\mathrm{AR}(1)$ \\
\hline & $(0.080)$ & & $(0.119)$ & \\
\hline \multirow[t]{2}{*}{ Population } & 0.000 & 0.503 & 2.806 & $\mathrm{AR}(1)$ \\
\hline & $(0.086)$ & & $(0.094)$ & \\
\hline \multirow[t]{2}{*}{ Mortgage rate } & -0.144 & 0.507 & 3.309 & $\mathrm{AR}(1)$ \\
\hline & $(0.249)$ & & $(0.069)$ & \\
\hline \multirow[t]{2}{*}{ Unemployment } & -0.008 & 0.493 & 2.887 & $\mathrm{AR}(1)$ \\
\hline & $(0.940)$ & & $(0.089)$ & \\
\hline 5 variables (ex-Income) & & 0.659 & 2.110 & $\mathrm{AR}(1)$ \\
\hline
\end{tabular}


$(0.146)$

NB: Probability is in parentheses; * significant at $5 \%$ level; the number of lags in the B-G test is 1.

The only problem with the current estimates is that the selected series (regardless of additional statistical inference) are insignificant. Only the employment series proved to be statistically significant at the level of 5 per cent. For Turkey, housing starts and population were significant at the level of 10 per cent. As noted above, in the case of the housing market in Ankara, none of the explanatory variables were statistically significant.

\subsubsection{Broadening Case and Shiller Framework}

An extension of the CASE and SHILLER (2003) framework was computed with a set of additional explanatory variables. These variables, selected in line with literature, included construction costs, construction permits, housing credit, construction credit, GDP per capita, money supply (M2), the stock market index and the inflation index (CPI). Table 5 displays the series' unit-root test results. Again, once the series passed statistical muster, they were regressed against housing price series. Table 6 below presents regression estimates for all series. The results are similar to CASE/SHILLER based calculations. As above, the national and Istanbul model computations explained around half of the housing price levels. This significance was less powerful for Izmir and Ankara.

Table 5

Unit-root test results for an extended Case-Shiller framework

\begin{tabular}{lcccc}
\hline \multirow{2}{*}{ Series } & \multicolumn{4}{c}{ Test results for the selected series } \\
\cline { 2 - 5 } & ADF & DF-GLS1 & PP & KPSS $^{2}$ \\
\hline Construction costs & -0.988 & -0.117 & -0.185 & 0.897 \\
\hline Construction costs (1-dif) & -2.713 & -2.501 & -1.974 & 0.084 \\
\hline Construction permits & -7.474 & -6.280 & -7.474 & 0.550 \\
\hline Housing credit & -1.187 & 1.035 & -1.185 & 0.939 \\
\hline Housing credit (1-dif) & -4.674 & -4.614 & -4.827 & 0.115 \\
\hline Construction credit & 0.337 & 0.241 & 0.912 & 0.924 \\
\hline Construction credit (1-dif) & -1.938 & -1.759 & -7.827 & 0.245 \\
\hline Construction credit (2-dif) & -6.351 & -4.462 & -21.104 & 0.073 \\
\hline Income & -1.919 & -0.028 & -3.725 & 0.921 \\
\hline Income (1-dif) & -1.516 & -1.483 & -3.847 & 0.457 \\
\hline Income (2-dif) & -6.706 & -1.183 & -21.420 & 0.186 \\
\hline Money supply (M2) & -0.664 & 1.171 & -0.653 & 0.908 \\
\hline Money supply (M2) (1-dif) & -6.891 & -6.955 & -6.851 & 0.066 \\
\hline Stock market index & -2.647 & -2.616 & -2.694 & 0.063 \\
\hline Stock market index (1-dif) & -8.099 & -5.408 & -8.187 & 0.061 \\
\hline Inflation index & 0.468 & 2.836 & 0.590 & 0.954 \\
\hline Inflation index (1-dif) & -6.507 & -6.079 & -6.438 & 0.115
\end{tabular}


Note: The test critical values (significance is at the level of 5 per cent) are as follows:

1) Augmented Dickey-Fuller (ADF) test: -2.912;

2) Dickey-Fuller (DF)- GLS (ERS) test: -1.947 ;

3) Phillips-Peron (PP) test: -2.912;

4) Kwiatkowski-Phillips-Schmidt-Shin (KPSS) test: 0.463;

${ }^{1}$ MacKinnon (1991, p. 275)

2 Kwiatkowski et al. (1992, p. 166)

Table 6

Regression estimates for an extended Case-Shiller framework

\begin{tabular}{|c|c|c|c|c|}
\hline Independent variables & Coefficient & R-sq. & B-G test & $\mathrm{AR}(\mathrm{p})$ \\
\hline \multicolumn{5}{|l|}{ Ankara } \\
\hline \multirow[t]{2}{*}{ Construction costs } & -0.011 & 0.218 & 0.178 & $\mathrm{AR}(1)$ \\
\hline & $(0.933)$ & & $(0.674)$ & \\
\hline \multirow[t]{2}{*}{ Construction permits } & 0.000 & 0.204 & 0.077 & $\mathrm{AR}(1)$ \\
\hline & $(0.852)$ & & $(0.781)$ & \\
\hline \multirow[t]{2}{*}{ Housing credit } & 0.000 & 0.217 & 0.198 & $\mathrm{AR}(1)$ \\
\hline & $(0.378)$ & & $(0.657)$ & \\
\hline \multirow[t]{2}{*}{ Construction credit } & 0.000 & 0.208 & 0.070 & $\mathrm{AR}(1)$ \\
\hline & $(0.781)$ & & $(0.792)$ & \\
\hline \multirow[t]{2}{*}{ Income } & 0.002 & 0.245 & 0.006 & $\mathrm{AR}(1)$ \\
\hline & $(0.108)$ & & $(0.938)$ & \\
\hline \multirow[t]{2}{*}{ Money supply (M2) } & 0.000 & 0.228 & 0.318 & $\mathrm{AR}(1)$ \\
\hline & $(0.131)$ & & $(0.573)$ & \\
\hline \multirow[t]{2}{*}{ Stock market index } & 0.000 & 0.213 & 0.122 & $\mathrm{AR}(1)$ \\
\hline & $(0.509)$ & & $(0.727)$ & \\
\hline \multirow[t]{2}{*}{ Inflation index } & 0.063 & 0.219 & 0.207 & $\mathrm{AR}(1)$ \\
\hline & $(0.395)$ & & $(0.649)$ & \\
\hline \multicolumn{5}{|l|}{ Istanbul } \\
\hline \multirow[t]{2}{*}{ Construction costs } & -0.232 & 0.446 & 0.624 & $\mathrm{AR}(2)$ \\
\hline & $(0.557)$ & & $(0.430)$ & \\
\hline \multirow[t]{2}{*}{ Construction permits } & 0.000 & 0.495 & 1.183 & $\mathrm{AR}(2)$ \\
\hline & $(0.200)$ & & $(0.277)$ & \\
\hline \multirow[t]{2}{*}{ Housing credit } & 0.000 & 0.498 & 1.392 & $\mathrm{AR}(2)$ \\
\hline & $(0.251)$ & & $(0.238)$ & \\
\hline \multirow[t]{2}{*}{ Construction credit } & 0.000 & 0.480 & 0.965 & $\mathrm{AR}(2)$ \\
\hline & $(0.528)$ & & $(0.326)$ & \\
\hline \multirow[t]{2}{*}{ Income } & 0.002 & 0.479 & 1.512 & $\mathrm{AR}(2)$ \\
\hline & $(0.402)$ & & $(0.219)$ & \\
\hline
\end{tabular}




\begin{tabular}{|c|c|c|c|c|}
\hline \multirow[t]{2}{*}{ Money supply (M2) } & 0.000 & 0.511 & 1.440 & $\mathrm{AR}(2)$ \\
\hline & $(0.060)$ & & $(0.230)$ & \\
\hline \multirow[t]{2}{*}{ Stock market index } & 0.000 & 0.523 & 1.915 & $\mathrm{AR}(2)$ \\
\hline & $(0.047)$ & & $(0.166)$ & \\
\hline \multirow[t]{2}{*}{ Inflation index } & 0.118 & 0.497 & 1.738 & $\mathrm{AR}(2)$ \\
\hline & $(0.152)$ & & $(0.187)$ & \\
\hline \multicolumn{5}{|l|}{ Izmir } \\
\hline \multirow[t]{2}{*}{ Construction costs } & 0.077 & 0.118 & 0.134 & $\mathrm{AR}(1)$ \\
\hline & $(0.455)$ & & $(0.714)$ & \\
\hline \multirow[t]{2}{*}{ Construction permits } & 0.000 & 0.129 & 0.075 & $\mathrm{AR}(1)$ \\
\hline & $(0.296)$ & & $(0.785)$ & \\
\hline \multirow[t]{2}{*}{ Housing credit } & 0.000 & 0.134 & 0.208 & $\mathrm{AR}(1)$ \\
\hline & $(0.488)$ & & $(0.648)$ & \\
\hline \multirow[t]{2}{*}{ Construction credit } & 0.000 & 0.157 & 0.015 & $\mathrm{AR}(1)$ \\
\hline & $(0.037)$ & & $(0.901)$ & \\
\hline \multirow[t]{2}{*}{ Income } & 0.000 & 0.094 & 0.011 & $\mathrm{AR}(1)$ \\
\hline & $(0.759)$ & & $(0.915)$ & \\
\hline \multirow[t]{2}{*}{ Money supply (M2) } & 0.000 & 0.133 & 0.108 & $\mathrm{AR}(1)$ \\
\hline & $(0.382)$ & & $(0.743)$ & \\
\hline \multirow[t]{2}{*}{ Stock market index } & 0.000 & 0.126 & 0.038 & $\mathrm{AR}(1)$ \\
\hline & $(0.855)$ & & $(0.845)$ & \\
\hline \multirow[t]{2}{*}{ Inflation index } & -0.105 & 0.148 & 0.289 & $\mathrm{AR}(1)$ \\
\hline & $(0.330)$ & & $(0.591)$ & \\
\hline \multicolumn{5}{|l|}{ Turkey } \\
\hline \multirow[t]{2}{*}{ Construction costs } & -0.013 & 0.471 & 3.565 & $\mathrm{AR}(1)$ \\
\hline & $(0.941)$ & & $(0.059)$ & \\
\hline \multirow[t]{2}{*}{ Construction permits } & 0.000 & 0.501 & 3.010 & $\mathrm{AR}(1)$ \\
\hline & $(0.239)$ & & $(0.083)$ & \\
\hline \multirow[t]{2}{*}{ Housing credit } & 0.000 & 0.496 & 2.860 & $\mathrm{AR}(1)$ \\
\hline & $(0.710)$ & & $(0.091)$ & \\
\hline \multirow[t]{2}{*}{ Construction credit } & 0.000 & 0.481 & 2.777 & $\mathrm{AR}(1)$ \\
\hline & $(0.785)$ & & $(0.096)$ & \\
\hline \multirow[t]{2}{*}{ Income } & 0.001 & 0.487 & 2.515 & $\mathrm{AR}(1)$ \\
\hline & $(0.337)$ & & $(0.113)$ & \\
\hline \multirow[t]{2}{*}{ Money supply (M2) } & 0.000 & 0.496 & 3.065 & $\mathrm{AR}(1)$ \\
\hline & $(0.528)$ & & $(0.080)$ & \\
\hline
\end{tabular}




\begin{tabular}{lcccc}
\hline Stock market index & 0.000 & 0.502 & 3.088 & $\mathrm{AR}(1)$ \\
\hline Inflation index & $(0.404)$ & & $(0.079)$ & \\
\hline & 0.030 & 0.496 & 2.807 & $\mathrm{AR}(1)$ \\
\hline
\end{tabular}

NB: Probability is in parentheses; * significant at $5 \%$ level; the number of lags in B-G test is 1 .

\subsubsection{Testing for bubbles with Rtadf}

Analysis resulting from right-tail variation of the standard ADF unit root test (Rtadf) further enhances the overall modelling framework by exploring the connection between explosive behaviors and a bubble in housing prices. We follow PWY and PSY methodologies for the application of Rtadf. In this respect, PHILLIPS, SHI and YU (2015) indicate that recursive right sided unit root tests seem to be particularly effective as real time detection mechanisms for mildly explosive behavior and market exuberance. In the Rtadf test, the null hypothesis is of a unit root and the alternative is of a mildly explosive autoregressive coefficient (CASPI 2016). We employ four variations of the Rtadf unit root test and all four test results appear to be significant for all four dependent variables (see Table 7). We find that, regardless of whether we are dealing with the aggregate Turkish housing market or regional series, neither test identifies a bubble period in Ankara, Istanbul, Izmir and Turkey over the period between 2010 and 2014.

Table 7

Rtadf test results

\begin{tabular}{lcccc}
\hline & ADF & max RADF & SADF & GSADF \\
\hline Turkey & 8.587 & 5.895 & 8.587 & 8.587 \\
\hline & $(0.000)$ & $(0.000)$ & $(0.000)$ & $(0.000)$ \\
\hline Ankara & 3.286 & 2.534 & 3.767 & 3.767 \\
\hline Istanbul & $(0.000)$ & $(0.006)$ & $(0.000)$ & $(0.001)$ \\
\hline & 10.206 & 3.768 & 10.206 & 10.206 \\
\hline Izmir & $(0.000)$ & $(0.000)$ & $(0.000)$ & $(0.000)$ \\
\hline & 4.194 & 5.776 & 5.002 & 5.776 \\
\hline
\end{tabular}

Abbreviations: ADF: Augmented Dickey-Fuller, max RADF: rolling window ADF test, SADF:

PWY supremum ADF test, GSADF: PSY generalized SADF test.

Note: for critical values and further modelling specification see CASPI (2016).

Despite some of the modelling restraints, the overall findings suggest that housing price inflation in Turkey, Istanbul, Ankara and Izmir is in line with the overall economic expansion and hence the Turkish housing market is not in a bubble over the period of Jan. 2010 - Dec. 2014. These results are in line with the general findings on the subject. Therefore, although housing market experienced a significant inflation over the last few years, it seems that the rise was mostly driven by fundamentals. Growing population, rising employment and income levels are all contributing to continuous housing inflation, especially in the national and Istanbul housing markets.

\section{Discussion and conclusions}

The combination of a growing economy and a stable macroeconomic environment places Turkey on the map as a country with a large growth potential in the post 2000s. The property sector has also gained dramatic momentum over the last decade and housing prices have shown noteworthy increases. In this respect, the CPI adjusted Turkey Housing Price Index (THPI) grew 34 per cent, 68 per cent, 13 per cent and 25 per cent in real terms in the national, Istanbul, Ankara, and Izmir housing markets, respectively, over the period of January 2010 to January 2015. However, real housing price 
appreciations have also created bubble concerns in aggregate/local levels. The current study stepped in to assess this claim, investigating whether the Turkish housing market was in a bubble.

The study employed three complementary methodologies. First, monthly/annual housing price-toincome (HPI) and monthly housing price-to-rent (HPR) housing affordability ratios were examined for Ankara, Istanbul, Izmir and Turkey over the period 2010 - 2014 for the first time in an academic study. Even though HPR ratios indicatively suggest overvaluations, we provide evidence that neither HPI nor HPR analyses clearly show the examined housing markets to be in a bubble due to the lack of dramatic/explosive movements in income, housing rent, and housing price series. Second, because affordability ratios may provide indicative information, a set of regressions were computed to advance housing bubble analysis over the period from 2010 to 2014. In the first part of the analysis, aiming to adopt the CASE and SHILLER (2003) framework, income, population, employment rate, unemployment rate, housing starts and mortgage interest rates were employed as the explanatory variables. Some of the modelling restraints notwithstanding, the overall findings suggested that the Turkish housing market responds to levels in employment, housing starts and population. The model with all 5 variables, which does not involve the income variable, improves model fit to 70 per cent, suggesting that a large proportion of the national housing series can be attributed to fundamentals. The model outcomes also provided additional information on regional housing price formation. In this respect, while homogeneity almost exists between the national and Istanbul housing markets, local characteristics would be more effective in Ankara and Izmir housing markets. An extended CASE-SHILLER modelling offered similar conclusions. Third, we employed four variations of the Rtadf unit root test and found that the Turkish housing market and regional series were not in a bubble during the period under analysis.

Overall, it is possible to suggest that the Turkish housing market was not in a bubble in the period from 2010 to 2014. Neither affordability ratios, nor the CASE-SHILLER, extended CASE-SHILLER regressions and Rtadf unit root test estimates suggested this to be the case. What is more, the public is not unusually excited about housing price inflation. The more fundamental attributes of market dynamics, such as a growth in home ownership, a decline in lending standards, lax regulation, the ease of obtaining funding, and a high degree of securitization are all absent. Therefore, it is reasonable to argue that housing prices in Turkey do not show bubble formation but noteworthy increases with some potential overvaluations over the period of 2010-2014. However, those concerned with housing should not be complacent. A greater oversight of housing finances, whether individual or corporate, monitoring of the construction industry, and market speculation analysis are just a few areas that market regulators should be looking at.

In further research, by also using local level variables, researchers can construct affordability series for all Turkish cities and employ various econometric models to analyze rational/irrational bubbles in Turkey. There is also the opportunity for further research by extending the data into the more recent time period.

\section{Acknowledgement}

The authors thank anonymous referees for their contributions and Fethi Öğünç for calculating the monthly GDP series.

\section{References}

AgNellO L., SCHUKNECHT, L., 2011, Booms and Busts in Housing Markets: Determinants and Implications, Journal of Housing Economics, No. 20, pp. 171-190. doi:10.1016/j.jhe.2011.04.001

AKERLOF, G.A., SHILlER, R.J., 2009, Animal Spirits: How Human Psychology Drives the Economy, and Why it Matters for Global Capitalism, Princeton University Press.

Ambrose, B.W., EichHOlTZ, P., Lindenthal, T., 2013, House Prices and Fundamentals: 355 Years of Evidence, Journal of Money, Credit and Banking, No. 45 (2-3): pp. 477-491.

AUGUSTYNIAK, H., LASZEK, J., OlSZEWSKI, K., WASZCZUK, J., 2013, Modeling of Cycles in the Residential Ral Estate Market-Interactions Between the Primary and the Secondary Market and Multiplier Effects, Working Paper, No. 143, National Bank of Poland.

BAKER, D., 2008, The Housing Bubble and the Financial Crisis, Real-World Economics Review, No. 46, pp. 73-81. 
BANK FOR INTERNATIONAL SETTLEMENTS, 2014, Residential Property Price Developments - Third Quarter of 2014, [Internet]. Available at: <http://www.bis.org/statistics/pp_residential.pdf >, [Accessed 07 April 2015].

BARLEVY G., 2007, Economic Theory and Asset Bubbles, Economic Perspectives, Federal Reserve Bank of Chicago, No. Q III, pp. 44-59.

BARLOWE, R., 1958, Land Resource Economics, Englewood Cliffs, NJ: Prentice-Hall.

BARRAS, R., 2009, Building Cycles: Growth and Instability (Real Estate Issues), Wiley-Blackwell, London, pp. 448.

Barth, J.R., LEA, M., LI, T., 2012, China's Housing Market: Is a Bubble About to Burst?, Milken Institute.

BESOMI, D., 2014, Crises and Cycles in Economic Dictionaries and Encyclopaedias, Routledge.

BINAY, S., SAlman, F., 2008, A Critique on Turkish Real Estate market. Discussion Paper, Working Paper, No. 2008/8, Turkish Economic Association.

Bjorklund, K., SODERBerg, B., 1999, Property Cycles, Speculative Bubbles and the Gross Income Multiplier, Journal of Real Estate Research, No. 18 (1): pp. 151-174.

Black, A., Fraser, P., Hoesli, M., 2006, House Prices, Fundamentals and Bubbles, Journal of Business Finance \& Accounting, No. 33(9-10), pp. 1535-1555.

BlANCHARD, O., WATSON, M., 1982, Bubbles, Rational Expectations and Financial Markets, Working Paper, No. 945, NBER.

BRAM, J., 2012, To Buy or not to Buy? The Changing Relationship Between Manhattan Rents and Home Prices, Federal Reserve Bank of New York Current Issues in Economics and Finance, No. 18 (9), pp. 1-7.

BroOKS, C., Tsolacos, S., 2010, Real Estate Modelling and Forecasting, Cambridge University Press.

BRUNNERMEIER, M.K., 2016, Bubbles. (in, Banking Crises: Perspectives from the New Palgrave Dictionary of Economics, Ed. Jones, G., Palgrave MacMillan ): pp. 28-37.

BrZezICKA, J., 2016, Speculative Bubbles And Their Components On The Real Estate Market-A Preliminary Analysis, Real Estate Management and Valuation, No. 24(1), pp. 87-99.

BuYuKdumAN, A. (2014), Bir Kent Efsanesi: Konut Balonu (An Urban Legend: Housing Bubble), Scala Yayıncılik, Istanbul (in Turkish).

CAmeron, G., Muellbauer, J., Murphy, A., 2006, Was There A British House Price Bubble? Evidence from a Regional Panel, Department of Economics Working Papers, No: 276, University of Oxford.

Canarella, G., Miller, S., Pollard, S., 2012, Unit Roots and Structural Change: an Application to US House Price Indices, Urban Studies, No. 49 (4), pp.757-776.

CASE, K.E., SHILLER, R.J., 2003, Is there a Bubble in the Housing Market?, Brookings Papers on Economic Activity, No. 2, pp. 299-342.

CASPI, I., 2016, Rtadf: Testing for Bubbles with EViews, November 6, working paper, Bank of Israel. Available at: <http://econ.biu.ac.il/files/economics/shared/riedp_4-16.pdf, [Accessed 6 February 2017].

CENTRAL BANK OF TURKey (CBRT), 2010, Methodological Information on the House Price Index, Available at: < http://www.tcmb.gov.tr/wps/wcm/connect/6c710268-4dfb-480a-9121faf89e5888f3/HPI_Methodological_Information.pdf?MOD=AJPERES\&CACHEID=ROOTWORKSP ACE6c710268-4dfb-480a-9121-faf89e5888f3 , [Accessed 26 January 2017].

CENTRAL BANK OF TURKEY (CBRT), 2015, Market Statistics [Internet]. Available at: <http:/ / evds.tcmb.gov.tr/index_en.html>, [Accessed 07 August 2015].

CHEN, K., WEN, Y., 2013, The Great Chinese Housing Boom: Causes, Consequences, and Future Paths, Tsinghua Workshop in Macroeconomics, Tsinghua University.

CoşKUN, Y., 2011, The Global Financial Crisis and the Turkish Housing Market: Is There a Success Story?, Housing Finance International, No. 25 (3), pp. 6-14.

CoşKun, Y., 2013, Housing-Construction Market Risks in Turkey: Overrated or Underestimated?, Housing Finance International, No. 26 (4), pp.47-55.

CoşKun, Y., WATKINS, C., WHITE, M., 2014, Macroeconomic Change, Housing Affordability and Public Policies: The Case of Turkey, Working Paper, 2014 ENHR Conference, 1-4 July, Scotland.

CoşKun, Y., ERTUĞRUL, M.H., SEVEN, U., AlP, A., 2017, Housing Price Dynamics and Bubble Risk: The Case of Turkey. Housing Studies (forthcoming).

CUSHMAN \& WAKEFIELD., 2014, Turkish Housing Market: Price Bubble, Market Report, Cushman \& Wakefield Research Publication. 
DEMOGRAPHIA, 2015, 12th Annual Demographia International Housing Affordability Survey: 2016. Available at: < http:/ / www.demographia.com/dhi.pdf >, [Accessed 07 June 2016].

DolPhIN T., GRIFFITH, M., 2011, Forever Blowing Bubbles: Housing Role in the UK Economy, Report in Institute for public policy research. London.

ELOY, C.M., ClAUDIA, F.C., 2014, Brazil's house price surge. Housing Finance International, Summer, pp. 17-26.

EMLAK KONUT GYO., 2014, Gayrimenkul ve Konut Sektörüne Bakış (Overview of Real Estate and Housing Sector), Market Report, [Internet]. Available at: <http://www.emlakkonut.com.tr/_ Assets/Upload/Status/EKGYO_01a.pdf \#.> [Accessed 06 April 2015] (in Turkish).

EROL, I., 2015, Türkiye'de Konut Balonu Var Mi? Konut Sektörü Kapitalizasyon Oranlarn Analizi (Is there a Housing Bubble in Turkey: Capitalization Ratio Analysis of Housing Sector), in Özçelik, E. and Taymaz, E (Eds)., Türkiye Ekonomisinin Dünü, Bugünü Yarını, Yakup Kepenek'e ve Oktar Türel'e Armağan [in Turkish], Imge Kitabevi Yayınları, pp. 323-344 [in Turkish].

FAWLEY, B.W., WEN, Y., 2013, The Great Chinese Housing Boom, Economic Synopses, No. 13, Federal Reserve Bank of St. Louis.

FENG, Q., Wu, G.L., 2015, Bubble or Riddle? An Asset-Pricing Approach Evaluation on China's Housing Market Economic Modelling, No. 46, pp. 376-83.

FERnÁNDEZ, R.B., 1981, Methodological Note on the Estimation of Time Series, Review of Economic and Statistics, no. 63 (3), pp.471-478.

FINANSINVEST, 2014, A Housing Price Bubble in Turkey? No, Not Yet, Market Report, 9 July.

FIPE ZAP, 2013, Indice Fipe Zap, [Internet]. Available at: <http://www.zap.com.br/imoveis/fipe-zapb/>, [Accessed 07 March 2015].

FORBES, 2014, Why the Worst is Still Ahead for Turkey's Bubble Economy, [Internet], Available at: <http://www.forbes.com/sites/jessecolombo ～/2014/03/05/why-the-worst-is-still-ahead-forturkeys-bubble-economy/\#.> [Accessed 10 February 2015].

Fox, R., TUlIP, P., 2014, Is Housing Overvalued?, Research Discussion Paper. RDP 2014-06. Reserve Bank of Australia.

Gallin, J., 2008, The Long-Run Relationship between House Prices and Rents, Real Estate Economics, no. 36 (4): pp.635-58.

Gerardi, K., FoOte, C., Willen, P., 2010, Reasonable People did Disagree: Optimism and Pessimism about the US Housing Market before the Crash", Discussion Paper, No.10-5, FRB of Boston.

GEYIK, E.U., 2012, Does Central Bank of Republic of Turkey React to Asset Prices?, No: 02 / 2012, Working Paper, Institute of Social Sciences, Namik Kemal University.

Girouard, N., Kennedy, M., NoOrd, P., AndrÉ, C., 2006, Recent House Price Developments: the Role of Fundamentals, Working Paper, no. 475 ECO/WKP(2006)3, OECD Economic Department.

Glindro, E.T., SubHANIJ, T., SZETO, J., ZHU, H., 2011, Determinants of House Prices in Nine Asia-Pacific Economies, International Journal of Central Banking, No. 7 (3), pp. 163-204

GoOdKIND, N., 2014, Roubini: We're in an Asset Bubble and it Won't Pop Until 2016, [Internet], Available at:<http:/ / finance.yahoo.com/news/roubini--u-s--equities-will-be-strong-until-2016133934757.html\#.> [Accessed 04 February 2015].

HalK YATIRIM, 2015, Makro Ekonomik Özel Not: Türkiye'de Konut Sektörü: 'Balon' Değil; Arz-Talep Dengesi (Housing Sector in Turkey: Not Bubble but the Equilibrium of Supply-Demand), [Internet], Available at: <http://www.halkyatirim.com.tr/Upload /2032015_93021714.pdf > [Accessed 5 August 2015] (in Turkish).

HimmelberG, C., Mayer, C., SinAi, T., 2005, Assessing High House Prices: Bubbles, Fundamentals and Misperceptions, Journal of Economic Perspectives, No. 19 (4), 67-92.

HLAvÁČEK, M., KOMÁREK, L., 2009, Housing Price Bubbles and their Determinants in the Czech Republic and its Regions, Working Paper, December, Czech National Bank.

Homm, U. AND Breitung, J., 2012, Testing for Speculative Bubbles in Stock Markets: A Comparison of Alternative Methods, Journal of Financial Econometrics, No. 10(1), pp. 198-231.

Hoyt, H., 1933, One Hundred Years of Land Values in Chicago, Chicago, IL: University of Chicago Press.

IMF, 2015a, Global Housing Watch: Quarterly Update, March. Available at: <http://www.imf.org/external/research/housing/report/pdf/0315.pdf>, [Accessed 06 April 2015].

IMF, 2015b, Price-to-Rent Ratio Data 2015q3, Available at: < http://www.imf.org/external/ research/housing/>, [Accessed 08 June 2015]. 
JADEVICIUS, A., HUSTON, S., 2014, A “family of cycles" - major and auxiliary business cycles. Journal of Property Investment $\mathcal{E}$ Finance, No. 32 (3), pp. 306-323.

JoebGeS, H., Dullien, S., MÁrqueZ-VelázQueZ, A., 2015, What causes housing bubbles? A theoretical and empirical inquiry, Study for the Macroeconomic Policy Institute, Hans-Böckler-Foundation, Düsseldorf. November. No. 43.

JONES, B., 2014, Identifying Speculative Bubbles: A Two-Pillar Surveillance Framework, Working Paper, IMF.

KARA, H., ÖĞÜNÇ, F. (2012), Döviz Kuru ve İthalat Fiyatlarinin Yurt İçi Fiyatlara Etkisi (Pass-Through from Exchange Rates and Import Prices to Domestic Prices), İtisat İşletme ve Finans, No. 27 (317), pp. 9-28 (in Turkish).

KARAMUJIC, M.K., 2013, Housing Affordability: Importance, Measures and an Empirical Assessment, University of Sarajevo School of Economics and Business, Sarajevo, Bosnia and Hercegovine.

KARASU, M. N., 2015, Understanding Real Estate Bubbles: An Analysis of the Recent Trends in the Turkish Housing Market, Dissertation, Master of Science, METU. Available at: <http:/ / etd.lib.metu.edu.tr/upload/12618979/ index.pdf>, [Accessed 15 September 2015].

KAyA, A., BOZKurt, A.T., BAŞTAN, E.M., AyAnOĞLU, O.A., 2012, Constructing a House Price Index for Turkey, Working Paper, July, BIS. Available at: <https://www.bis.org/ ifc/events/6ifcconf/ kayaetal.pdf $>$, [Accessed 07 March 2015].

KHOLDY, S., SOHRABIAN, A., 1998, Economic Fundamentals and Housing Market, Applied Economics Letters, 5 (7), pp. 459-461.

Kindleberger, C.P., 2001, Manias, Panics and Crashes: A History of Financial Crises (Wiley Investment Classics), 4th. Ed., John Wiley \& Sons.

Kindleberger, C.P., AliBer, R.Z., 2005, Manias, Panics, and Crashes: A History of Financial Crises. 5th.ed., John Wiley \& Sons.

Kosareva, N., Tumanov, A., 2008, Assessing Housing Affordability in Russia, Problems of Economic Transition, no. 50 (10), pp. 6-29.

KRAINER, J., WEI, C., 2004, House Prices and Fundamental Value, FRBSF Economic Letter. 2004-27.

KRUGMAN, P., 2005, That Hissing Sound, NYTIMES[Internet], Available at: <http://www.nytimes.com/2005/ 08/08/opinion/08krugman.html?_r=0>, [Accessed 12 February 2015].

KWIATKOWSKI, D., PHILliPS, P.C.B., ScHMIDT, P., SHIN, Y., 1992, Testing The Null Hypothesis Of Stationarity Against The Alternative Of A Unit Root: How Sure Are We That Economic Time Series Have A Unit Root?, Journal of Econometrics, No. 54 (1-3), pp.159-178.

MACKINNON, J.G., 1991, Critical Values for Cointegration Tests, in: Engle, R.F. and Granger, C.W.J., Longrun Economic Relationships: Readings in Cointegration, Oxford University Press.

MallicK, H., MAHALIK, M.K., 2012, Fundamental or Speculative Factors in the Housing Markets of Emerging Economies? Some Lessons from China. Journal of Economic Policy Reform, No. 15 (1), pp. 57-67.

MARTIN, R. 2011, The Local Geographies of the Financial Crisis: From the Housing Bubble to Economic Recession and Beyond, Journal of Economic Geography, No. 11 (4), pp. 587-618.

MAYER, C., 2011, Housing Bubbles: a Survey, Annual Review of Economics, Vol. 3, pp. 559-577.

MengJIE, L., REED, R., WU, H., 2008, Challenges Facing Housing Affordability In Beijing In The Twenty-First Century, International Hournal of Housing Markets and Analysis, No. 1 (3): pp. 275-287.

Miller, M., Stiglitz, J., 2010, Leverage and Asset Bubbles: Averting Armageddon With Chapter 11?, The Economic Journal, No. 120 (544), pp. 500-518.

MoInAS, S., Pouget, S., 2013, The Bubble Game: An Experimental Study of Speculation, Econometrica, No. 81 (4), pp. 1507-1539.

MoODY'S, 2016, Announcement: Moody's: Mortgage Covered Bonds among Safest Credit Instruments in Turkey, Issuance May Increase, [Internet]. Available at: < https://www.moodys.com> [Accessed 26 May 2016].

NEWEY, W.K., WEST, K.D., 1987. A Simple, Positive Semi-Definite, Heteroskedasticity and Autocorrelation Consistent Covariance Matrix, Econometrica, no. 55 (3), pp.703-708.

NumbeO, 2015, Property prices index for country 2015 mid-year, [Internet]. Available at: <http://www.numbeo.com/property-investment/rankings_by_country.jsp>, [Accessed 05 August 2015]. 
OECD, 2005, Recent House Price Developments: The Role of Fundamentals, in OECD Economic Outlook, No. 78, Chapter III, pp. 123-154.

PhilliPs, P.C.B., Wu, Y., AND YU, J., 2011, Explosive Behavior in the 1990s Nasdaq: When did Exuberance Escalate Asset Values?, International Economic Review, No. 52, pp. 201-226.

PhILliPS, P.C.B, SHI, S.-P. AND YU, J., 2015, Testing for multiple bubbles: historical episodes of exuberance and collapse in the S\&P 500. International Economic Review, no. 56 (4), pp. 1043-1078.

Pitros, C. AND ARAYICI, Y., 2016, How to Identify Housing Bubbles? A Decision Support Model, International Journal of Housing Markets and Analysis, No. 9 (2), pp. 190-221.

Pitros, C., COSKUN, Y, ARAYICI, Y., 2017, Is there a Bubbly Euphoria in the Turkish Housing Market? (forthcoming)

RAPOZA, K., 2015, Brazil Housing Bubble Deflates, but Still Quite Large, Forbes. [Internet]. Available at: < http:/ / www.forbes.com/sites/kenrapoza/2015/01/08/brazil-housing-bubble-deflates-but-stillquite-large/>, [Accessed 06 March 2015].

REBUCCI, A., 2014, Are Emerging Markets Ready for the Housing Earthquake? ${ }_{\llcorner}$FT. [Internet]. Available at: <http://ftalphaville.ft.com /2015/02/04/2112501/are-emerging-markets-ready-for-the-housingearthquake/>, [Accessed 06 April 2015].

REBUCCI, A., 2015, The Emerging Markets Housing Bubble, 2/27/2015, Huffington Post, [Internet]. Available at: <http://www.huffingtonpost.com/jon-hartley/the-emerging-marketshousing_b_6627590.html >, [Accessed 06 April 2015].

REIDIN, 2015, Market Statistics, [provided by special permission].

REN, Y., XIONG, C., YUAN, Y., 2012, House Price Bubbles in China, China Economic Review, No. 23, pp. $786-800$.

Republic Of Turkey Ministry Of ECONOMy (RTME). (2012), Foreign Direct Investments in Turkey 2011, April. Available at: <http://www.economy.gov.tr/upload/C161EFB8-A8F3-60383B618342F8BA89B1/FDI_2011.PDF>, [Accessed 05 July 2015].

RODRIK, D., 2012, The Turkish Economy after the Global Financial Crisis, Ekonomi-tek, No. 1 (1), pp. 41-61.

RoubinI, N., 2013, Housing Bubble 2.0 Can only End Badly, The Guardian. [Internet], Available at: <http:/ / www.theguardian.com/business/2013/dec/02/housing-bubble-bust-recession>, [Accessed 12 February 2015].

SCHMIDT, B., CASTELlANI, M., 2013, Shiller Warns of Housing Bubble after 225\% Surge: Brazil Credit [Internet]. Available at: <http://www.bloomberg. com/news/articles/2013-09-05/shiller-warnsof-housing-bubble-after-225-surge-brazil-credit/>, [Accessed 06 March 2015].

SHEN, Y., HuI, E. C., LiU, H., 2005, Housing Price Bubble in Beijing and Shanghai, Management Decision, no. 43(4), pp. 611-627.

SHILLER, R.J., 1992, Market Volatility, Massachusetts: MIT Press.

SHILlER, R.J., 2005, The Bubble's New Home, [Internet], Available at: <http://online.barrons.com/ articles/SB111905372884363176?tesla=y>, [Accessed 12 February 2015].

SHILLER, R. J., 2006, Irrational Exuberance, 2nd.ed., Crown Business.

SHILlER, R.J., 2012, The Subprime Solution: How Today's Global Financial Crisis Happened, and What to Do about it, Princeton University Press.

SHILLER, R.J., 2013, Finance and the Good Society. Princeton University Press.

SHILler, R.J., 2014a, Speculative Asset Prices (Nobel Prize Lecture), Discussion Paper, No. 1936, Cowles Foundation, Yale University.

SHILLER, R.J., 2014b, Robert Shiller on Brazil Housing Bubble, [Internet]. Available at: <http://world.yale.edu/videos/robert-shiller-brazil-housing-bubble>, [Accessed 06 March 2015].

SMITH, M.H., SMITH, G., 2006, Bubble, Bubble, where's the Housing Bubble?, Brookings Papers on Economic Activity, 37 (1), pp. 1-50.

SMith V.L., SuCHANEK, G.L., Williams, A.W., 1988, Bubbles, Crashes, and Endogenous Expectations in Experimental Spot Asset Markets, Econometrica, 56, 1119-1151.

STANDARD \& POOR'S, 2015, Housing Markets in Israel, Russia, South Africa, and Turkey Show Resilience to Weaker Economic Conditions, Economic Research, [Internet], Available at: <http://rusipoteka.ru /files/analytics/sandp/2015/1703.pdf>, [Accessed 7 April 2015].

StiglitZ, J., 2007, House of Cards, The Gaurdian [Internet], Available at: <http://www.theguardian.com/ commentisfree/2007/oct/09/housesofcards>, [Accessed 12 February 2015]. 
The Brookings Institution, 2015, Global Metro Monitor 2014, Parilla, J. Trujillo, J.L. and Berube, A. and Ran, T. (Eds.), [Internet], Availble at: <http://www.brookings.edu / /media/Research/ Files/Reports/2015/01/22-global-metro-monitor/bmpp_GMM_final. pdf?la=en>, [Accessed 6 April 2015].

THE ECONOMIST, 2015, Global House Prices, [Internet], Available at: <http://www.economist.com /blogs/dailychart/2011/11/global-house-prices>, [Accessed 05 August 2015].

The FinANCIAL TiMes, 2014, Turkey's Construction Boom Appears to be Over, Nov 27, FT [Internet]. Available at: <http://www.ft.com/cms/s/0/910a4a32-5093-11e4-8645-00144feab7de.html\#axzz 3ZFWjFcL9 >, [Accessed 5 April 2015].

THE FinANCIAL TIMES, 2015, Turkey: A Flagging Growth Story, May 18.

THE NEW YORK TIMES, 2014, Alarm over Istanbul's Building Boom, NYTIMES [Internet], Available at: <http://www.nytimes.com/2014/05/21/realestate/ commercial / after-istanbuls-building-boomcome-worries-of-a-bust.html?_r=1>, [Accessed 5 April 2015].

TSAI, C.I., 2013, Housing Affordability, Self-Occupancy Housing Demand and Housing Price Dynamics, Journal of Habitat International, no. 40, pp. 73-81.

TRULIA, 2016, House Price to Rent. [Internet], Available at: <http://www.trulia.com/ >, [Accessed 5 July 2015].

TURKSTAT, 2015a, Market Statistics \& News Bulletin, May 31, No: 18727.

TURKSTAT, 2015b, Data Set: Seasonally Adjusted Indices Based on Individual Questions Concerning the Construction Sector Tendency, [Internet], Available at: <http://www.tuik.gov.tr/Pre>, [Accessed 5 August 2015].

TURKSTAT, 2016, Data Set: Gross Domestic Product Per Capita by Provinces, 2004-2014, [Internet], Available at: <http://www.tuik.gov.tr/PreHaberBultenleri.do?id=24920>, [Accessed 10 February 2017].

ULI and PWC, 2012, Emerging Trends in Real Estate Europe, market report, pp.60.

UNCTAD, 2014, World Investment Report 2014: Investing in the SDGs: an Action Plan, United Nations Conference on Trade and Development.

WANG, Z., ZHANG, Q., 2014, Fundamental Factors in the Housing Markets of China, Journal of Housing Economics, 25, pp. 53-61.

WAtson, K., 2014, Brazil Property Prices: Fears of 'Bubble' in Home Costs', [Internet], Available at: <http:/ / www.bbc.co.uk/news/business-27218510>, [Accessed 06 March 2015].

WeISE, A. D., PHILIPS, J. W., HochHEIM, N., 2015, Cyclicity of Housing Markets under the Specific Condition of the Existence of a Bubble in the Real Estate Market, Real Estate Management and Valuation, No. 23(3), pp. 85-98.WORLD BANK, 2015, Indicators [Internet]. Available at: <http://data.worldbank. org/indicator>, [Accessed 07 April 2015].

YALCINER, K., CoşKun, Y., 2014. Conditions of Mortgage Market Development: A Critical Empirical Review for Turkey, İktisat İşletme Finans, No. 29 (339), pp. 59-94.

ZARnOWITZ, V., 1992, Business Cycles: Theory, History, Indicators, and Forecasting, University of Chicago Press, Chicago.

ZEREN, F., ERGUZEL, O.Ş., 2015,. Testing For Bubbles in the Housing Market: Further Evidence from Turkey, Financial Studies, No. 19 (1), pp. 40-52. 